\title{
YUMURTA İKAMESİ OLARAK KULLANILAN ÇİYA VE KETEN TOHUMU JELININ PANKEK HAMURU REOLOJİSİ VE ÜRÜN ÖZELLİKLERİ ÜZERİNE ETKİSINIIN İNCELENMESİ
}

\author{
Selen Erkoç ${ }^{1}$, İpek Özcan ${ }^{1}$, Esra Özyiğit ${ }^{2}$, Seher Kumcuoğlu ${ }^{1}$, Şebnem Tavman ${ }^{*}$ \\ ${ }^{1}$ Ege Üniversitesi, Gıda Mühendisliği Bölümü, İzmir, Türkiye \\ ${ }^{2}$ Manisa Celal Bayar Üniversitesi, Gıda Mühendisliği Bölümü, Manisa, Türkiye
}

Geliş / Received: 30.03.2021; Kabul / Accepted: 06.09.2021; Online bask1 / Published online: 06.11.2021

Erkoç, S., Özcan, İ., Özyiğit, E., Kumcuoğlu, S., Tavman, Ş. (2021). Yumurta ikamesi olarak kullanulan çiya ve keten tohumu jelinin pankek hamuru reolojisi ve ürün özellikleri üzerine etkisinin incelenmesi. GIDA (2021) 46 (6) 1397-1414 doi: 10.15237/gida.GD21098.

Erkoç, S., Özcan, İ., Özyiğit, E., Kumcuoğlu, S., Tavman, Ş. (2021). Investigation of the effects of chia and flaxseed gel used egg replacers on pancake batter rheology and product properties. GIDA (2021) 46 (6) 1397-1414 doi: 10.15237/gida.GD21098.

\section{ÖZ}

Bu çalısmada, yumurta beyazı ikamesi olarak çiya ve keten tohumu jeli ilavesinin pankek hamurunun reolojik özellikleri ve pankek örneklerinin bazı kalite özellikleri üzerine etkileri incelenmiştir. Çiya ve keten tohumu jeli yumurta beyazı ikamesi olarak iki farklı oranda (\%50, \%100) kullanılmıştır. Pankek hamurlarının akış davranışlarının üssel model ile açıklanabildiği $\left(\mathrm{R}^{2}=0.987-0.998\right)$ ve örneklerin kayma ile incelen davranış gösterdiği saptanmıştır. Çiya ve keten tohumu jelinin kullanımıyla elastik $(G)$ ve viskoz modül $\left(G^{\prime \prime}\right)$ değerlerinin arttığı görülmüştür. Çiya ve keten tohumu jeli oranının artmasılla örneklerin protein içeriğinin azaldığı $(P<0.05)$ belirlenmiştir. Taramalı elektron mikroskobu görüntülerinden formülasyondaki çiya ve keten tohumu jeli oranlarının artmasıyla örneklerdeki gözenekliliğin azaldığı ve çiya tohumu jelinin artmasıyla örneklerin daha katmanlı ve kırılgan bir yapı gösterdiği gözlemlenmiştir.

Anahtar kelimeler: Yumurta ikameleri, bitkisel yumurta ikameleri, çiya tohumu, keten tohumu, reoloji

\section{INVESTIGATION OF THE EFFECTS OF CHIA AND FLAXSEED GEL USED EGG REPLACERS ON PANCAKE BATTER RHEOLOGY AND PRODUCT PROPERTIES}

\begin{abstract}
In this study, the effects of the addition of chia and flaxseed gel as egg white replacers on the rheological properties of pancake batter and some quality properties of pancake samples were investigated. Chia and flaxseed gel were used in two different proportions $(50 \%, 100 \%)$ as egg white replacers. It has been revealed that the flow behavior properties of pancake batters can be explained by the power law model $\left(\mathrm{R}^{2}=0.987-0.998\right)$ and the samples exhibited shear-thinning behavior. The use of chia and flaxseed gel increased the elastic $\left(G^{\prime}\right)$ and viscous modulus $\left(G^{\prime \prime}\right)$ values. It was

\footnotetext{
* Yazışmalardan sorumlu yazar / Corresponding author

1 sebnem.tavman@ege.edu.tr

(1): (+90) 2323113016

冝: (+90) 2323114831
}

Selen Erkoç; ORCID no: 0000-0003-2188-4119

İpek Özcan; ORCID no: 0000-0003-2923-2772

Esra Özyiğit; ORCID no: 0000-0003-2579-2828

Seher Kumcuoğlu; ORCID no: 0000-0002-3663-2881

Şebnem Tavman; ORCID no: 0000-0002-6042-7482 
determined that the protein content decreased with increased ratio of chia and flaxseed gel $(P<0.05)$. By examining the scanning electron microscope images, porosity of the samples decreased with the increase of chia and flaxseed gel, and the samples showed a more layered and fragile structure with the increase of chia seed gel.

Keywords: Egg replacers, plant based egg replacers, chia seed, flaxseed, rheology

\section{GİRİ̧̧}

Yumurta, yüksek protein içeriğine sahip olmasının yanı sıra, jel oluşturma, köpük oluşturma, kıvam arttırma, emülsifiye etme, renklendirme gibi çeşitli fonksiyonel özellikleri nedeniyle de gida uygulamalarında sıkça kullanılan temel bileşenlerden biridir (Uysal vd., 2019). Ancak, yumurta tüketimi ile ilişkili çeşitli sağlık riskleri (kalp-damar hastalıkları, yumurta alerjisi) veya tüketicilerin vegan beslenmeye yönelik tercihleri yumurta yerine kullanilabilecek alternatif kaynakların araştırılmasına neden olmaktadır (Agrahar-Murugkar vd., 2016; Shi vd., 2011). Bu nedenle çeşitli bitkisel proteinler (bezelye proteini, soya proteini), hayvansal proteinler (kolajen, hidrolizatlar, jelatin, peynir altı suyu konsantresi vb.), buğday nişastası, hidrokolloidler ve emülgatörlerin yumurta yerine kullanımıyla ilgili çalışmalar gerçekleştirilmiştir (Kohrs vd., 2010; Tan vd., 2015).

Bitkisel proteinler, nispeten ucuz bir alternatif olmakla birlikte hayvansal proteinlerle karşılaştırılabilir derecede besleyici ve fonksiyonel özelliklere sahip olmalarından dolayı gida endüstrisinin ilgisini çekmektedir (Sharif vd., 2018). Ayn1 zamanda bu ilgi, modern tüketicilerin sürdürülebilirlik ve sağllk konusunda farkındalığının artması ile de desteklenmektedir (Boye vd., 2010; McClements vd., 2017; Sharif vd., 2018). Genellikle ticari olarak kullanılan bitkisel protein kaynakları yağlı tohumlar, tahıllar ve baklagillerdir (Çetiner ve Ersus Bilek, 2018). Zengin besin içeriği dolayısıyla önemli bitkisel protein kaynaklarından olan keten ve çiya tohumları da su ile karıştırıldıklarında jel oluşturma yeteneğine sahiptir. Bu özelliğiyle, keten ve çiya tohumlarından elde edilen jeller yumurta ikamesi olarak kullanıma uygun gidalar arasinda yer almaktadır (Chen vd., 2006).

Çiya; zengin besin öğesi içeriği ve su tutma özelliği nedeniyle gıda endüstrisinde bütün halde, ögütülerek, su içinde jel halinde veya kuru halde kıvam arttırıcı, emülgatör ve stabilizatör olarak kullanılmaktadır (Zettel ve Hitzman, 2018; Hrncic vd., 2020). Çiya tohumu kendi ağırllğından daha fazla su tutma ve su ile karıştırıldığında hızlıca jel oluşturma özelliğine sahiptir (Özbek vd., 2018; Yurt ve Gezer, 2018). Çiya jeli, sağladığ1 reolojik ve duyusal özelliklerle beraber mükemmel stabilite ve emülsifiye edici etki göstermesi nedeniyle potansiyel bir yumurta ikamesi olarak görülmektedir (Agrahar-Murugkar vd., 2016; Gallo vd., 2020).

Keten (Linum usitatissimum L.) önemli bir yağlı tohum mahsulüdür ve lignanlar, fenolikler, tokoferoller, karotenoidler, yüksek kaliteli çoklu doymamış yağ asitleri (omega-3), diyet lifleri ve antioksidanlar açısından zengindir (Mannucci vd., 2019). Keten tohumunun fonksiyonel özelliklerinde en büyük rolü içerdiği proteinler üstlenmektedir. Keten tohumu proteinleri emülsifiye etme, jel oluşturma, köpük oluşturma ve stabil etme gibi fonksiyonel özelliklerinden dolayı gida endüstrisinde etkili bir kıvam arttırıc1, stabilizatör ve emülgatör olarak kullanilabilmektedir (Rabetafika vd., 2011; Safdar vd., 2019). Günlük diyette keten tohumu direkt tohum halinde tüketilebildiği gibi gida sektöründe tohumu veya yağ1 çeşitli ürünlerin içinde fonksiyonel bir gida bileşeni olarak kullanılmaktadır. Mükemmel bir Omega-3 ve diyet lifi kaynağı olan keten tohumu, kaynatıldığında viskoz bir jel oluşturmaktadır (Rabetafika vd., 2011; Kajla vd., 2015). G1da sektöründe yumurta ikamesi olarak kullanılmasının en önemli nedenlerinden birisi nötral polisakkaritlerden oluşan müsilaj içeriğidir (Tirgar vd., 2017). Keten tohumunun kuru ağırlığının \%8’ini müsilaj oluşturmakta ve suda çözünerek düşük konsantrasyonlarda jel oluşturabilmektedir (İşleroğlu ve Yıldırım, 2005).

Yumurta ikamesi olarak keklerde çiya tohumu kullanımı (Borneo vd., 2010; Gallo vd., 2020; Agrahar-Murugkar vd., 2016) ve keten tohumu 
kullanımı (Nugraheni vd., 2019) üzerine gerçekleştirilen çeşitli çalışmalar bulunmaktadır. Borneo vd. (2010) tarafindan kek örneklerinde yumurta ikamesi olarak farklı oranlarda çiya jeli kullanımının keklerin fonksiyonel, besinsel ve duyusal özelliklerine olan etkisi incelenmiştir. Çiya jelinin çikolatalı kekte yumurta ikamesi olarak kullanıldığ1 diğer bir çalışmada ise ikame kullanımının duyusal özelliklerde olumsuz etki yaratmadığ1 tespit edilmiştir (Gallo vd., 2018). Nugraheni vd. (2019) çalışmasında, glutensiz ve yumurta içermeyen kurabiye geliştirilmesinde yumurta ikamesi olarak keten tohumu jeli kullanımının fiziksel, besinsel ve duyusal özellikler üzerine etkisini incelemiştir. Ancak, pankek örneklerinde yumurta ikamesi olarak çiya ve keten tohumu jellerinin kullanımına daha az dikkat çekilmiştir.

Pankek, un, yumurta, tuz, yağ, şeker kullanılarak hazırlanan kahvaltılık veya tatlı olarak tüketilen, genellikle ince, yuvarlak, yassı bir kektir (Finnie vd., 2006; Incoronato vd., 2020). Farklı ülkelerde farklı tariflerle bilinmekle birlikte, Fransa ve Japonya'da krep, Kore'de gözleme, ülkemizde ise akıtma, kaş1k dökmesi ve tava keki olarak tüketilmektedir. Sulu bir hamur yapısına sahip olan pankekte pişirilirken hafif ve kabarı bir doku gözlenmektedir (Cho vd., 2019). Yumurta ikamesi olarak çiya ve keten tohumu jeli kullanımı hamur yapısında değişikliklere neden olarak son üründe etkili olmaktadır. Gıda sistemlerinde unların ve tohumların suyu absorplama ve şişme özelliklerini tanımlayan, ürünlerin kıvamı ile yapısı hakkında bilgi veren su absorplama indeksi (WAI), yapıda meydana gelen değişimlerin belirlenmesinde değerlendirilmektedir (Choi vd., 2012). Hamurların viskoelastik özelliklerinin tanımlanmasında, elastik modül $\left(G^{\prime}\right)$ değerleri ve viskoz modül $\left(G^{\prime \prime}\right)$ değerleri incelenerek yapıda baskın karakterin belirlenmesi sağlanmaktadır. Akış davranış özellikleri ise akış davranış indeksi (n) ve kivam indeksi $(K)$ değerleri incelenerek belirlenmektedir. $n$ değeri akış davranışı hakkında bilgi vermekte ve $n=1, n<1, n>1$ olacak şekilde sırasıyla Newton tipi akış, kayma ile incelme ve kayma ile kalınlaşma özelliklerini tanımlamaktadır (Singh ve Heldman, 2014). $K$ ise gidalarda viskoz davranışın bir göstergesi olmaktadır (Koocheki et al. 2009).

Çalışma kapsamında yumurta beyazı ikamesi olarak çiya ve keten tohumu jeli kullanılarak çeşitli nedenlerle yumurta tüketmeyen bireylerin tüketimine uygun pankek geliştirilmesi, çiya ve keten tohumu jelinin yumurta ikamesi olarak kullanımının hamur reolojisi ve pankek kalitesi üzerine olan etkilerinin incelenmesi amaçlanmıştır.

\section{MATERYAL ve YÖNTEM}

\section{Materyal}

Çiya ve keten tohumu jellerinin üretiminde çiya ve keten tohumu (Yayla Agro Gıda San. ve Nak. A.Ş, Ankara) kullanılmıştır. Pankek örneklerinin üretiminde buğday unu (Söke, Aydın), yumurta beyazı, şeker, tuz, su, vanilya, kabartma tozu (DrOetker Gida San. ve Tic. A.Ş., İzmir) ve farklı oranlarda çiya tohumu ve keten tohumu jelleri kullanılmıştır.

\section{YÖNTEM}

Çiya ve Keten Tohumu Jelinin Hazırlanması Çiya jeli, Borneo vd. (2010) tarafindan belirtilen yöntem kullanılarak hazırlanmıştır. Buna göre çiya tohumları, çiya tohumu:su oranı 1:9 $(\mathrm{g} / \mathrm{g})$ olacak şekilde 30 dakika suda bekletilmiştir. Keten tohumu jeli El-Sayed vd. (2014) tarafindan belirtilen yöntem modifiye edilerek hazırlanmıştır. Keten tohumu, keten tohumu:su oran1 1:20 (g/ml) olacak şekilde $100^{\circ} \mathrm{C}$ 'de 30 dakika boyunca suyla karıştırılarak 8 saat oda sıcaklığında bekletilmiş, daha sonra keten tohumları ayrılarak jel elde edilmiştir.

\section{Pankek Örneklerinin Üretimi}

Pankek örneklerinin hazırlanmasında Shih vd. (2006) tarafindan kullanılan yöntem modifiye edilmiştir. Çiya $(\% 50,100)$ ve keten tohumu $(\% 50,100)$ jelleri formülasyona ayr1 ayrı olacak şekilde yumurta beyazı ile yer değiştirilerek ilave edilmiştir. Sadece yumurta beyazı içeren örnek kontrol (K) olarak adlandırılmıştır. Pankek örneklerinin formülasyonları Çizelge 1'de belirtilmiştir. 
Pankek hamurunun hazırlanmasi amaciyla kuru malzemelerin tümü karıştırılmışırı. Çiya tohumu jeli/keten tohumu jeli ve su ayr1 bir kapta karıştırıldıktan sonra kuru malzemeler siv1 malzemelere eklenerek, 45 saniye boyunca spatula yardımıyla karıştırılmıştır. Karıştırma işleminden sonra $40 \mathrm{~g}$ hamur önceden yağlanmış ve isıtılmış bir tavada 3 dakika pişirildikten sonra diğer yüzü çevrilip 3 dakika pişirilmiştir.

Çizelge 1. Farklı oranlarda yumurta ikamesi olarak çiya tohumu jeli ve keten tohumu jeli ile oluşturulan pankek örneklerinin formülasyonu (g)

Table 1. Pancake Formulation (g)

\begin{tabular}{|c|c|c|c|c|c|}
\hline $\begin{array}{l}\text { Malzemeler } \\
\text { (Ingredients) }\end{array}$ & $\begin{array}{l}\mathrm{K} \\
(C)\end{array}$ & $\begin{array}{l}\% 50 \mathrm{C} \\
(50 \% \mathrm{C})\end{array}$ & $\begin{array}{l}\% 100 \mathrm{C} \\
(100 \% \mathrm{C})\end{array}$ & $\begin{array}{l}\% \text { \%50 KT } \\
(50 \% \text { FS) }\end{array}$ & $\begin{array}{l}\% 100 \mathrm{KT} \\
(100 \% \mathrm{FS})\end{array}$ \\
\hline Buğday unu (wheat flour) & 100 & 100 & 100 & 100 & 100 \\
\hline $\begin{array}{l}\text { Yumurta beyaz1 (egg } \\
\text { white) }\end{array}$ & 40 & 20 & 0 & 20 & 0 \\
\hline $\begin{array}{l}\text { Keten tohumu jeli/Çiya } \\
\text { tohumu jeli (Flaxseed } \\
\text { gel/Cbia seed gel) }\end{array}$ & 0 & 20 & 40 & 20 & 40 \\
\hline Şeker (Sugar) & 20 & 20 & 20 & 20 & 20 \\
\hline Tuz (Salt) & 2 & 2 & 2 & 2 & 2 \\
\hline $\begin{array}{l}\text { Kabartma tozu (Baking } \\
\text { powder) }\end{array}$ & 4.5 & 4.5 & 4.5 & 4.5 & 4.5 \\
\hline Su (Water) & 108.5 & 108.5 & 108.5 & 108.5 & 108.5 \\
\hline
\end{tabular}

K: Kontrol örneği (K: Control sample)

\%50 C: \%50 çiya tohumu jeli içeren pankek örneği (50\% C: Pancake sample containing 50\% chia seed gel)

\%100 C: \%100 çiya tohumu jeli içeren pankek örneği (100\% C: Pancake sample containing 100\% chia seed gel)

\%50 KT: \%50 keten tohumu jeli içeren pankek örneği (50\% FS: Pancake sample containing 50\% flaxseed gel)

\%100 KT: \%100 keten tohumu jeli içeren pankek örneği (100\% FS: Pancake sample containing 100\% flaxseed gel)

Çiya ve Keten Tohumunda Gerçekleştirilen Analizler

Ciya ve Keten Tohumunun Su Absorplama Indeksinin Belirlenmesi

Çiya ve keten tohumlarının su absorplama indeksi (WAI) değerleri, Choi vd. (2012)'de verilen yöntem modifiye edilerek belirlenmiştir. $3 \mathrm{~g}$ keten tohumu veya çiya tohumu $30 \mathrm{ml}$ distile su ile karıştırilıp su banyosunda $60^{\circ} \mathrm{C}^{\prime}$ de 1 saat bekletilmiştir. Daha sonra örnek Universal 320R santrifüj kullanılarak (Hettich Zentrifugen, Tuttlingen, Almanya) 4000 rpm'de 15 dakika santrifüj edilmiş ve elde edilen çökelti tartılmıştır. Örneklerin su absoplama indeksi Eşitlik (1) ile hesaplanmışır.

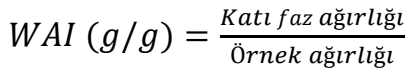

Ciya ve Keten Tobumu Jelinin Protein Miktarmm Belirlenmesi

Yumurta ak1, çiya tohumu jeli ve keten tohumu jelinin protein içeriği FP-528 Nitrogen/Protein Analizörü (Leco, St. Joseph, ABD) kullanılarak belirlenmiştir. Analiz öncesinde örnekler Alpha 12 LD plus liyofilizatör (Martin Christ, Göttingen, Almanya) ile $-56^{\circ} \mathrm{C}^{\prime}$ de 48 saat kurutulmuştur.

\section{Fourier Dönüşümlü Kızılötesi Spektroskopisi (FTIR) Analizi}

Çiya tohumu jeli ve keten tohumu jelinin yapılarının analiz edilmesi amaciyla Fourier Dönüşümlü Kızıl Ötesi Spektrometresi kullanılmıştır. Çiya tohumu jeli ve keten tohumu jeli örneklerinin kızılötesi spektrumları, Spectrum Two Zayıflatılmış Toplam Yansıma (ATR)- FTIR cihaz1 (Perkin Elmer, Waltham, ABD) kullanilarak 4000-600 $\mathrm{cm}^{-1}$ dalga boyunda ölçülmüştür (Rosas-Mendoza vd., 2017).

\section{Pankek Hamurunda Gerçekleştirilen Analizler \\ Yoğunluk}

Pankek hamurlarında yoğunluk ölçümü $100 \mathrm{ml}$ hacme sahip Elcometer 1800 piknometre (Elcometer, Manchester, İngiltere) kullanilarak gerçekleştirilmiştir. Piknometre analiz öncesinde 
boş olarak tartılmış ve daha sonrasında hamur örnekleri piknometreye doldurulmuştur. Fazla örnek temizlendikten sonra tartım alınıp elde edilen değer kaydedilmiştir. Yoğunluk değerleri örneklerin kütlelerinin hacimlerine bölünmesiyle elde edilmiştir (Gularte vd., 2012).

\section{Reolojik Özellikler}

Kek hamurlarında reolojik özelliklerin belirlenmesi amaciyla DHR-3 reometre (TA Instruments Inc., New Castle, ABD) kullanılmıştır. Hazırlanan hamur örnekleri bekletilmeden analiz edilmişlerdir. Analizler $25 \pm 0.1^{\circ} \mathrm{C}$ 'de, plakalar arası boşluk $1 \mathrm{~mm}$ olacak şekilde $40 \mathrm{~mm}$ çaplı paralel plaka kullanılarak gerçekleştirilmiştir. Örneklerin doğrusal viskoleastik özellik gösterdiği bölgenin tespit edilmesi amaciyla, $10 \mathrm{rad} / \mathrm{s}$ sabit frekansta ve $10^{-2}$ -100 gerinim aralığında gerinim tarama testi gerçekleştirilmiştir. Analiz sonucunda belirlenen sabit gerinim değerinde $0.01-10 \mathrm{~Hz}$ aralığında frekans tarama testi gerçekleştirilmiştir. Frekans tarama testi ile hamurun elastik modül $\left(G^{\prime}\right)$, viskoz modül $\left(G^{\prime}\right)$, tan $\delta$ değerlerinin frekans ile değişimi incelenmiştir. Örneklerin akış davranışlarını belirlemek amaciyla, kayma hız1 0.01-100 $\mathrm{s}^{-1}$ aralığında lineer olarak arttırılarak gerçekleştirilen analiz sonucunda, kayma gerilimi ve görünür viskozitenin kayma hızı ile değişimi değerlendirilmiştir. Elde edilen verilere Üssel (Power Law) model (2) uygulanarak akış davranışı belirlenmiştir (Ronda vd., 2011).

$\sigma=K_{c p} \cdot \dot{\gamma}^{n}$

Eşitliklerde verilen $\sigma$, kayma gerilimini $(\mathrm{Pa}), \dot{\gamma}$; kayma hızını $(1 / \mathrm{s}), K_{\phi p}$; kıvam indeksini $\left(\mathrm{Pa} . \mathrm{s}^{\mathrm{n}}\right)$ ve $n$ akış davranışı indeksini göstermektedir. Analizler 2 paralel, 3 tekrar olacak şekilde gerçekleştirilmiş ve sonuçların ortalaması verilmiştir.

\section{Pankek Örneklerinde Gerçekleştirilen Analizler \\ Bilesim}

Örneklerin bileşimlerini belirlemek amacıyla nem, kül, ham yağ ve protein analizleri gerçekleştirilmiştir. Buna göre analizler, nem değerleri metot AACC (2000) 44-15A, kül miktarı AACC (2000) metot 08-01, ham yağ miktar1
AACC (2000) metot 30-25 ve protein değerleri AACC (2000) metot 46-30'a göre gerçekleştirilmiştir.

\section{Doku Profil Analizi}

Örneklerin doku profili analizi, pişirme işleminden 24 saat sonra TA-XT2i Tekstür analizörü (StableMicrosystems, Surrey, İngiltere) cihaz1 ile Fajardo ve Ross (2015) tarafindan belirtilen yöntem modifiye edilerek gerçekleştirilmiştir. Analiz, $25 \mathrm{~mm}$ çaplı alüminyum silindirik prob ile $2 \mathrm{~mm} / \mathrm{s}$ test hızında, trigger kuvveti $50 \mathrm{~g}$ ve $\% 50$ gerilim ile gerçekleştirilmiştir.

\section{Renk}

CM-400d Minolta Colour Reader (Konica Minolta, Osaka, Japonya) kullanılarak örneklerin yüzey ve iç rengi belirlenmiştir. Farklı örneklerde, farklı oranlarda çiya tohumu jeli veya keten tohumu jeli kullanımının etkisi L* (parlaklık), a* (+ kırmız1, - yeşil), b* (+ sarı, - mavi) renk değerleri ölçülerek belirlenmiştir (Bozdogan vd., 2019).

\section{Duyusal değerlendirme}

Farkl1 oranlarda yumurta beyaz1 ikamesi olarak çiya tohumu jeli ve keten tohumu jeli ile oluşturulan pankek örneklerinin duyusal değerlendirmesi Ege Üniversitesi Gida Mühendisliği Bölümündeki öğretim elemanı ve lisansüstü öğrencilerinden yar1 eğitilmiş 10 panelistin katılımıla gerçekleştirilmiştir. Örneklerin duyusal değerlendirmesinde hedonik skala testi kullanılarak panelistlerin 5 farklı pankek örneklerini görünüş, renk, doku, lezzet ve genel beğeni kategorilerinde puanlamaları istenmiştir. Duyusal değerlendirme için kullanılan hedonik skala "Çok Kötü”: 1, "Kötü”: 2, “Orta”: 3, “İyi”:4 ve "Çok İyi": 5 olmak üzere puanlandırılmıştır (Altuğ Onoğur ve Elmac1, 2015).

\section{Taramalı Elektron Mikroskopisi (SEM)}

Üretilen örneklerin mikro-yapısının belirlenmesi amacıyla taramalı elektron mikroskopisi kullanılmıştır. Pişirilen örnekler, iç kısımlarından 1 $\mathrm{cm}^{3}$ hacminde küpler kesilerek Alpha 1-2 LD plus liyofilizatör (Martin Christ, Göttingen, Almanya) ile $-56^{\circ} \mathrm{C}$ 'de 24 saat kurutulmuş ve altın 
ile kaplanmıştır. SEM analizi, Apreo S taramalı elektron mikroskobu (Thermo Scientific, Waltham, ABD) ile gerçekleştirilmiştir. Görüntüler 1000x büyütme oranında alınmıştır.

\section{İstatistiksel analiz}

Deneysel veriler farklı formülasyonlar arasında önemli fark $(P<0.05)$ bulunup bulunmadı̆̆ını belirlemek için tek yönlü varyans analizi (ANOVA) kullanılarak istatistiksel olarak değerlendirilmiştir. Önemli düzeyde fark bulunduğunda karşılaştırma için Duncan çoklu karşılaştırma testi kullanılmıştır.

\section{SONUÇ ve TARTIŞMA}

\section{Çiya ve Keten Tohumu Özellikleri}

Ciya ve Keten Tobumunun Su Absorplama İndeksi

Keten tohumu ve çiya tohumunun ögütülmüş halinde belirlenen WAI değerlerinin sirasıyla, 3.55 ve $5.83 \mathrm{~g} / \mathrm{g}$ olduğu saptanmıştır (Çizelge 2). Literatürde çiya tohumu ve keten tohumunun su absorplama indeksleri (WAI) sirasiyla 5.1 ve 3.77 g/g olarak tespit edilmiştir (Hatamian vd., 2020; Kumar vd., 2019). Pankek formülasyonunda keten tohumu ve çiya tohumu jellerinin kullanımının örneklerin su absorplama indekslerini etkileyerek yapıda değişikliğe neden olduğu düşünülmektedir. Yapılan bir çalışmada da çiya tohumu jelinin protein içeriğinden dolayı iyi bir su absorplama kapasitesine sahip olduğu ortaya konmuştur (Olivos-Lugo vd., 2010).

Çizelge 2. Çiya ve keten tohumlarının su absorplama indeksleri

Table 2. Water absorption indexes of chia and flaxseed

\begin{tabular}{ll}
\hline Örnek (Sample) & WAI $(\mathrm{g} / \mathrm{g})$ \\
\hline Çiya Tohumu (chia seed) & $5.83 \pm 0.12^{\mathrm{b}}$ \\
Keten Tohumu (flaxseed) & $3.55 \pm 0.08^{\mathrm{a}}$ \\
\hline
\end{tabular}

Aynı sütundaki farklı harfler istatistiksel açıdan fark olduğunu göstermektedir $(P<0.05)$.

Different letters in the same column $(a, b)$ indicate a statistically significant difference $(P<0.05)$

\section{Çiya ve Keten Tohumu Jellerinin Protein Miktarının Belirlenmesi}

Yumurta ak1, çiya tohumu jeli ve keten tohumu jelinin protein içeriği Çizelge 3'te verilmiştir. $\% 72.75$ ile en yüksek protein içeriğine sahip örneğin yumurta beyazı olduğu saptanmıştır $(P$ $<0.05)$. Çiya tohumu jeli ve keten tohumu jelinin protein içeriği sırasılyla $\% 4.50$ ve $\% 4.9$ olarak tespit edilmiştir. Keten tohumu jelinin protein içeriği çiya tohumu jelinden biraz daha yüksek olsa da aralarında istatistiksel açıdan anlamlı bir fark bulunamamıştır $(P>0.05)$. Yumurta beyazı yaş temelde yaklaşık $\% 9.7-\% 10.6$ proteine sahipken çiya tohumu jelinin ise kuru temelde \%3.5 proteine sahip olduğu bildirmiştir (Mine, 1995; Coorey vd., 2014). Bu çalışmada da literatür ile uyumlu şekilde, yumurta beyazının protein içeriği keten ve çiya tohumu jelinden daha yüksek bulunmuştur.

Çizelge 3. Yumurta akı, çiya tohumu jeli ve keten tohumu jelinin protein miktarı değerleri

Table 3. Protein content of egg white, chia seeed gel and flaxseed gel

\begin{tabular}{ll}
\hline Örnek (Sample) & $\begin{array}{l}\text { Protein miktar1* } \\
\text { (Protein content) }\end{array}$ \\
\hline Yumurta beyaz1 (Egg white) & $72.75 \pm 0.27^{\mathrm{b}}$ \\
Çiya tohumu jeli (cbia seed gel) & $4.50 \pm 0.18^{\mathrm{a}}$ \\
Keten tohumu jeli (flaxseed gel) & $4.90 \pm 0.96^{\mathrm{a}}$ \\
\hline
\end{tabular}

Aynı sütundaki farklı harfler istatistiksel açıdan fark olduğunu göstermektedir $(P<0.05)$.

Different letters in the same column (a, b) indicate a statistically significant difference $(P<0.05)$

*Kuru temelde * Dry basis

\section{FTIR analizi}

Çiya tohumu jeli ve keten tohumu jeli örneklerinin kimyasal bileşimlerini karakterize etmek amacıyla FTIR spektroskopisinden yararlanılmıştır. Çiya tohumu jeli ve keten tohumu jelinin FTIR spektrumu Şekil 1'de verilmiştir. Çiya tohumu jeli örnekleri için 3100-3700 $\mathrm{cm}^{-1}$ aralığındaki bantlar, protein içeriğinin $(\mathrm{N}-\mathrm{H})$ gerilmesini temsil etmektedir. Ayrica $1700-1550 \mathrm{~cm}^{-1}$ ve $1600-1980$ $\mathrm{cm}^{-1}$ bölgesi, proteini karakterize eden Amid I gruplarının varllğını göstermektedir. Çiya tohumu jeli durumunda $1500-1900 \mathrm{~cm}^{-1}, 1550 \mathrm{~cm}^{-1}, 1400$ $\mathrm{cm}^{-1}$ bantlar1, saptanan üronik asit varlığına katılmış olan üronik asitlerin karboksil grubunun (-COO-) göstergesidir. Çiya tohumu ve jeli için $1654 \mathrm{~cm}^{-1}$ ve $1618 \mathrm{~cm}^{-1}$ 'deki iletim bantlar1 mannoz halkasinı temsil etmektedir. Ek olarak, çiya tohumu için $1750 \mathrm{~cm}^{-1}$ ve $1200 \mathrm{~cm}^{-1}$, piranoz halkasinda bulunan $\mathrm{C}=\mathrm{O}$ ve C-O-C'yi temsil etmektedir. $1080 \mathrm{~cm}^{-1}$ 'de bant, $1 \rightarrow 4$ glikosidik bağ halkası titreşimi ve C-OH bükülmesinin C-OC'sini göstermekte ve polisakkaritlerin özelliği 
olarak kabul edilmektedir (Darwish vd., 2018). Keten tohumu jeli için $1600 \mathrm{~cm}^{-1} \mathrm{C}=\mathrm{O}$ asimetrik germe titreşimi, keten tohumu jelindeki bağlı suyun varllğını gösteren karboksil grubuna bağlıdır. Karboksil grubu iyonlar için bir bağlanma yeri görevi görmesi nedeniyle jelleşme ve reolojik özellikler üzerinde büyük bir etkiye sahiptir. $1400 \mathrm{~cm}^{-1}$ deki emilim, C - O germe titreşimi olarak adlandırılmakla birlikte üronik asitlerin varlığını göstermektedir. $800-1200 \mathrm{~cm}^{-1}$ arasındaki alan karbonhidratlar için parmak izi bölgesi olarak kabul edilmektedir. $1100 \mathrm{~cm}^{-1}$ de gözlenen pik glikozidik bağlarının $\mathrm{YC}-\mathrm{O}-\mathrm{C}$ ve C-
OH varlığını göstermektedir. Ayrıca, $1020 \mathrm{~cm}^{-1}$ 'deki emilim, glukan birimlerinin varlığı hakkında bilgi vermektedir. $3100 \mathrm{~cm}^{-1}$ de gözlemlenen geniş ve güçlü bir tepe, hidroksil grubunun $(\mathrm{OH})$ gerilme titreşiminin varllğını göstermektedir (Fang vd., 2020). Çiya tohumu ve keten tohumundan elde edilen jellerin literatürdeki diğer çiya ve keten tohumu jel örnekleri ile benzer FTIR spektrumları sergilediği görülmüştür (Deng vd., 2020; Muñoz-González vd., 2019; Safdar vd., 2020; Safdar vd., 2019; Darwish vd., 2018; Fang vd., 2020).

a)

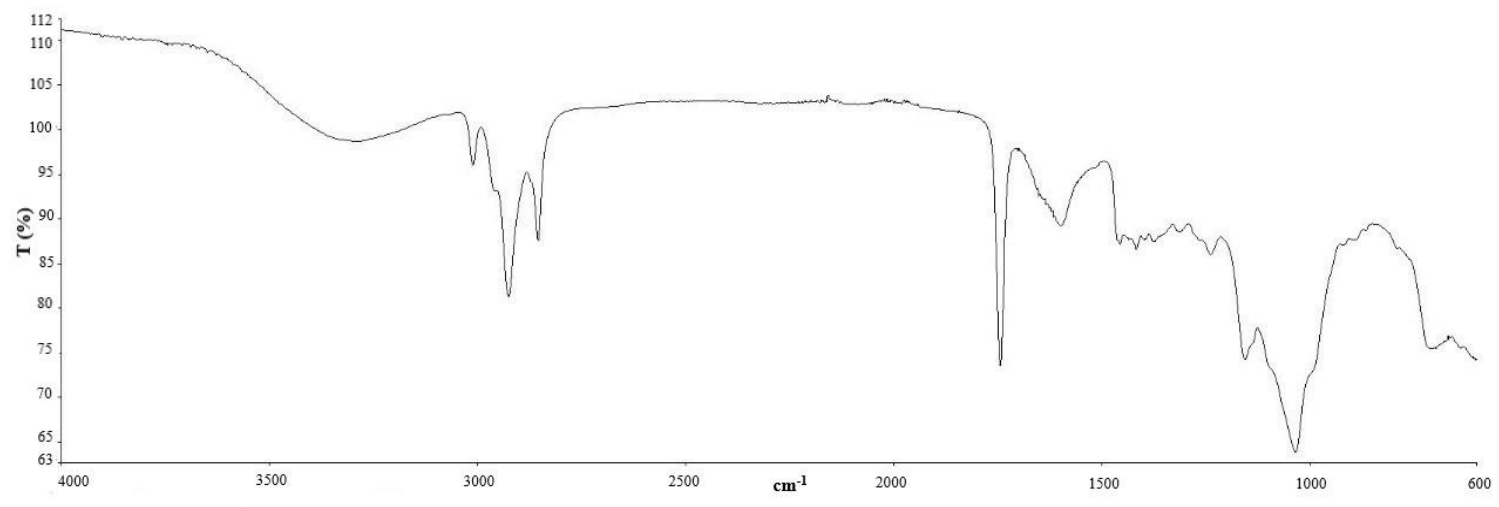

b)

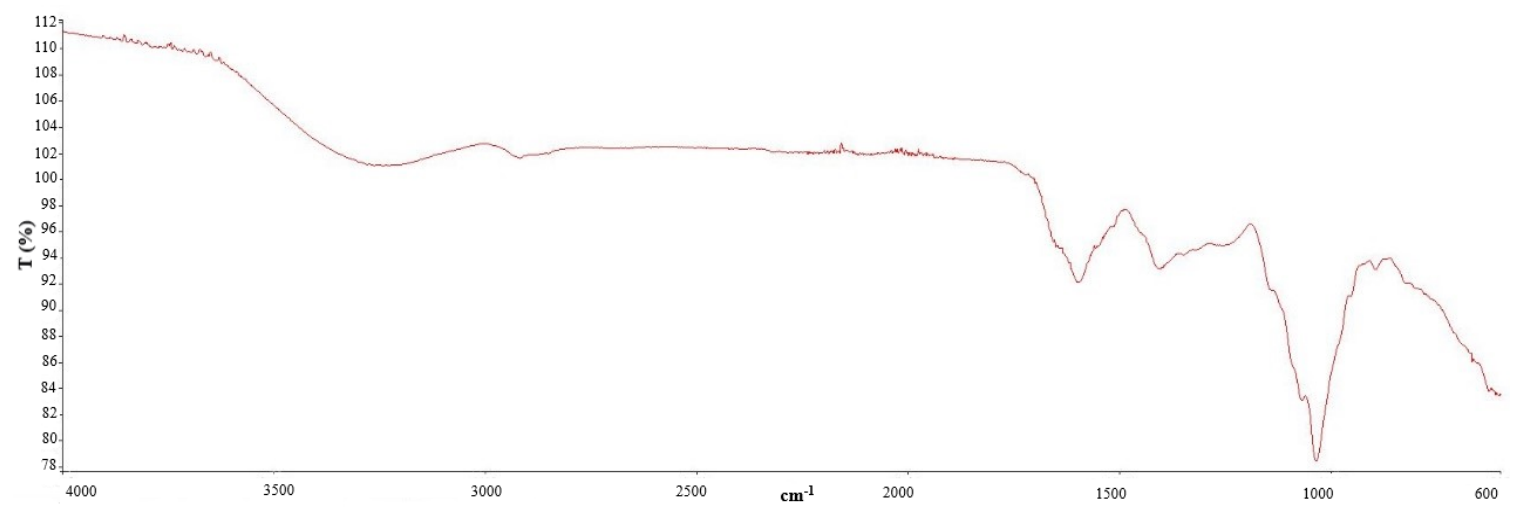

Şekil 1. Çiya tohumu ve keten tohumu jelinin FTIR spektrumu. a) çiya tohumu jeli; b) keten tohumu jeli

Figure 1. FTIR spectrum of chia seed gel and flaxseed gel. a) chia seed gel; b) flaxseed gel

\section{Pankek Hamur Özellikleri}

Yoğunluk

Farklı oranlarda yumurta ikamesi kullanılarak elde edilen hamurların yoğunluk değerleri 1.086-1.132 $(\mathrm{g} / \mathrm{ml})$ arasında değişiklik göstermekte olup, çiya ve keten tohumu kullanımının örneklerin yoğunluk değerlerinde artışa neden olduğu saptanmıştır $(P<0.05)$ (Çizelge 4). Hamurların yoğunluk değeri, hamur içerisinde tutulan hava miktarının bir göstergesi olarak kabul 
edilmektedir. Hamur içerisinde bulunan hava miktarı arttıkça, yoğunluk değeri düşerek yüksek hacimli ürün elde edilmektedir (Gómez et al., 2007).

Çizelge 4. Farklı oranlarda çiya ve keten tohumu jeli içeren örneklere ait yoğunluk değerleri Table 4. Density of samples containing different proportions of chia and flaxseed gel.

\begin{tabular}{lc}
\hline Örnek (Sample) & $\begin{array}{c}\text { Yoğunluk }(\mathrm{g} / \mathrm{ml}) \\
\text { (Density } \mathrm{g} / \mathrm{ml}))\end{array}$ \\
\hline Kontrol (Control) & $1.086 \pm 0.01^{\mathrm{a}}$ \\
$\% 50 \mathrm{KT}(50 \% \mathrm{FS})$ & $1.115 \pm 0.009^{\mathrm{b}}$ \\
$\% 100 \mathrm{KT}(100 \% \mathrm{FS})$ & $1.268 \pm 0.002^{\mathrm{e}}$ \\
$\% 50 \mathrm{C}(50 \% \mathrm{C})$ & $1.16 \pm 0.007^{\mathrm{d}}$ \\
$\% 100 \mathrm{C}(100 \% \mathrm{C})$ & $1.135 \pm 0.008^{\mathrm{c}}$ \\
\hline
\end{tabular}

Aynı sütunda bulunan değerler arasında farklı harf içeren örnekler arasında istatistiksel olarak anlamlı fark bulunmaktadır $(P<0.05)$.

Different letters in the same column $(a, b, c, d, e)$ indicate significant differences between means $(P<0.05)$.

\section{Reolojik Özellikler}

Akış davranış1

Yumurta ikamesi olarak çiya ve keten tohumu jeli kullanımının hamurların akış davranış Özelliklerine olan etkisi 0.01-100 s-1 kayma hiz1 aralığında incelenmiştir (Şekil 2). Kayma hızı arttıkça keten tohumu jeli içeren örneklerde kayma gerilimi değerleri artış gösterirken, çiya tohumu jeli içeren örneklerde, $\% 50$ çiya tohumu jeli içeren örneklerde azalma, $\% 100$ çiya tohumu jeli içeren örneklerde ise artı̧s olduğu belirlenmiştir. Kayma hızına karşlık kayma gerilimi grafiğinden elde edilen deneysel verilere en iyi uyumun üssel model ile elde edildiği gözlemlenmiştir ( $\left.R^{2}=0.987-0.998\right)$. Üssel model uygulanarak belirlenen kıvam katsayısı $(K)$ ve akış davranış indeksi (n) Çizelge 5'te belirtilmektedir. Elde edilen $n$ değerleri $0.352-0.490$ aralığında değişmekte ve kayma ile incelen özellik göstermektedir $(P<0.05)$. $K$ değerleri, 18.33233.997 Pa.s ${ }^{n}$ aralığında değişmekte ve keten tohumu içeriği arttıkça kıvam indeksi değerleri artış göstermekte; en yüksek $K$ değeri ise $\% 100$ çiya tohumu jeli içeren örnek olarak bulunmuştur $(P<0.05)$.
Yumurta ikamesi olarak farklı tohum jeli kullanımı sonucunda örneklerin viskozite değerlerinde, $\% 50$ çiya tohumu jeli içeren örnek dişında viskozite değerlerinde artş̧ olduğu belirlenmiştir. Hamur örneklerinde yüksek su absorplama kapasitesine sahip bileşenlerin kullanımı, partiküllerin serbest su içerisindeki hareketliliğini azaltarak, görünür viskozite değerlerini arttırmaktadır (Ronda vd., 2011). Çiya ve keten tohumu jeli ile hazırlanan örneklerin de yüksek su absorplama kapasitelerine bağlı olarak hamurların görünür viskozite değerlerini arttırdığ1 görülmektedir. Tüm örneklerde kayma hızı arttıkça görünür viskozite değerlerinde azalma gözlemlenerek, kayma ile incelen (psödoplastik) yap1 görülmektedir. Yumurta ikamesi olarak çiya tohumu kullanılan bir çalışmada örneklerin akış davranışının, Casson model ve Herschel Bulkley modele uyumluluğu incelenmiştir. Buna göre çiya tohumu ile hazırlanan örneklerde Casson ve Herschel Bulkley modellere uyumun oldukça düşük olduğu ve elde edilen $\mathrm{r}^{2}$ değerlerinin sırasıyla 0.46 ve 0.52 olduğu belirtilmiştir (Agrahar-Murugkar vd., 2016). Benzer şekilde kek örneklerinde yumurta ikamesi olarak peynir altı suyu proteinin kullanıldığı bir çalışmada hamurların akış davranış özelliklerinin Power Law modele uyumluluğu incelenmiş ve peynir altı suyu proteini kullanımı ile $n$ değerlerinin yumurta içeren örneklere kiyasla artış gösterdiği (0.2-0.5); kıvam indeksi değerlerinde $(k)$ ise azalma olduğu (0-160 Pa.s") belirlenmiştir (Tan vd., 2015).

Reolojik özellikler doğrusal bölgede gerilim ve gerinime bağlı olmamakta ve belli bir gerinim değerinden sonra modül değerleri azalarak doğrusal olmayan bölgeye geçiş yapılmaktadır. Bu nedenle frekans tarama testlerinden önce örneklerin doğrusal bölgede olduğu aralık belirlenmektedir (Steffe, 1996). Tüm pankek hamur örneklerinin elastik modül $\left(G^{\prime}\right)$ değerleri, viskoz modül $\left(G^{\prime \prime}\right)$ değerlerinden daha yüksektir ve hamurun yapisında elastik karakter baskın olmaktadır (Şekil 3). \%50 çiya tohumu jeli içeren örnek hariç pankek hamur formülasyonunda tohum jeli kullanım oranı arttıkça elde edilen elastik ve viskoz modül değerleri de artış göstermektedir. Su absorplama kapasitesi yüksek çiya ve keten tohumu jeli kullanımı ile partiküllerin 
hareketliliğinin azalması sonucu viskoelastikliğin de artı̧̧ gösterdiği düşünülmektedir. Benzer şekilde, glutensiz muffin hamurlarında farklı su absorplama kapasitesine sahip protein kaynaklarının kullanımında, WAI değerinin artmasına bağlı olarak elastik ve viskoz modül değerlerinin de arttığı belirtilmiştir (Shevkani vd. 2015).

Örneklerin viskoelastik davranışları gerilim tarama testi sonucunda belirlenen sabit gerinim değerinde, gerinim oranının uygulanmasıyla hamurların viskoz ve elastik davranıslarındaki değişim kaydedilerek belirlenmektedir (Steffe, 1996). Frekans tarama testi ile elde edilen sonuçlara göre jel içeriği arttıkça örneklerin elastik modül değerlerinin artış gösterdiği gözlemlenmiştir. Viskoz modül değerleri incelendiğinde ise tohum jeli ile hazırlanan örneklerde kontrol grubuna karşılık artış olduğu görülmektedir (Şekil 4). Elastik modül değerleri, tüm örnek grupları için viskoz modül değerlerinden daha yüksek bulunmuştur. Dolayısıyla kayıp tanjant değerleri $(\tan \delta)$ değerleri 1 'den küçük olmakta ve örnekler kat1 elastik benzeri yap1 göstermektedir (Weipert, 1990). Çiya tohumu jelinin yüksek su absorplama kapasitesine sahip olması hamurların elastikiyetini arttırması ile ilişkilendirilebilmektedir (Moreira vd., 2013). Lee vd. (2004), çalışmalarında yulaf kepeği ve keten tohumunu pastacılık yağ1 ikamesi olarak kek örneklerinde kullanmış ve hamur örneklerinin $G^{\prime}$ ve $G^{\prime \prime}$ değerlerinin frekansla değişimini incelemişlerdir. Buna göre $10^{-2}$ ve $10^{2} \mathrm{~Hz}$ aralığında, örneklerde yağ ikamesi olarak keten tohumu içeriğinin arttırılmasıyla $G^{\prime}$ ve $G^{\prime \prime}$ modül değerlerinin $10^{2}-10^{4}$ aralığında frekansa bağlı olarak artış gösterdiği belirtilmiştir.

\section{Pankek Örneklerinin Özellikleri \\ Bilessim}

Çizelge 6'da yumurta beyazı ikamesi olarak çiya tohumu jeli ve keten tohumu jeli kullanımının pankek örneklerinin nem, kül, yağ ve protein değerleri üzerine olan etkisi verilmektedir. Örneklerin nem içeriğinin \%45.94 ve $\% 49.85$ aralığında değiştiği, çiya tohumu jeli kullanılarak hazırlanan örneklerin en yüksek nem içeriğine sahip olduğu belirlenmiştir $(P<0.05)$. Hargreaves ve Zandonadi (2018) tarafından yapılan çalışmada da glutensiz kek örneklerinde formülasyona çiya tohumu jeli eklenmesi ile nem içeriğinin arttı̆̆1 gözlemlenmiştir. Çiya tohumu jeli ve keten tohumu jeli içeren örneklerin daha yüksek nem içeriğine sahip olması, çiya ve keten tohumunun su absorplama, jel oluşturma ve protein ağıyla interaksiyona girebilme özellikleri ile açıklanabilmektedir (Hargreaves ve Zandonadi, 2018; Zettel ve Hitzman, 2018; Rabetafika vd., 2011). Örneklerin protein içeriğinin \%7.48 ile \%4.4 arasında değiştiği gözlemlenmiştir. En yüksek protein içeriğine sahip örneğin kontrol örneği, en düşük protein içeriğine sahip örneğin ise $\% 100$ çiya tohumu jeli içeren örnek olduğu tespit edilmiştir $(P<0.05)$. Jel örneklerinin protein içeriği incelendiğinde (Çizelge 3), keten tohumu jeli ile çiya tohumu jeli arasında istatistiksel açıdan fark tespit edilmese de değerler arasında az bir farkla keten tohumu jelinin protein içeriğinin daha yüksek olduğu görülmektedir. Bu doğrultuda, aynı oranda çiya tohumu jeli ve keten tohumu jeli içeren pankek örneklerine bakıldığında keten tohumu jeli içeren örneklerin daha yüksek protein içeriğine sahip olduğu tespit edilmiştir $(P<0.05)$. Bu çalışmada elde eldilen bulgulara benzer şekilde, Hargreaves ve Zandonadi (2018), çiya tohumu jeli ve keten tohumu jeli kullanarak hazırladığ1 keklerin protein içeriğinin \%5.92 ile 5.69 arasında değiştiğini bildirmiştir. Örneklerin kül ve yă̆ değerlerinde çiya tohumu jeli ve keten tohumu jelinin kullanımı ile anlamlı bir fark gözlemlenmemiştir $(P>0.05)$.

\section{Doku Profil Analizi}

Farklı formülasyonlar kullanılarak hazırlanan pankek örnekleri; sertlik, esneklik, yapışkanlık, sakızımsılık, çiğnenebilirlik ve elastiklik açısından incelenmiş; sonuçlar Çizelge 7'de verilmiştir. Kullanilan yumurta ikamesi tipi ve oranı örneklerin sertlik değerlerinde anlamlı bir fark oluşturmuştur $(P<0.05) . \% 100$ keten tohumu jeli içeren pankek en sert örnek olurken \%100 çiya tohumu jeli içeren pankek örneği ise en yumuşak örnek olmuştur. En yüksek yoğunluğa sahip hamurun \%100 keten tohumu jeli içeren hamur olduğu tespit edilmiştir. Hamur yoğunluğunun artmas1 sonucunda hamurda tutulan hava kabarcıkları azalmakta ve daha sert yapıda ürün 
oluşmaktadır. Levent vd. (2020) tarafindan yapılan çalışmada keten tohumu içeren keklerin kontrol örneğinden daha sert olduğu, AgraharMurugkar vd. (2016) tarafından yapılan çalışmada ise çiya tohumu içeren örneklerin kontrol örneğinden daha yumuşak olduğu tespit edilmiştir.

a)

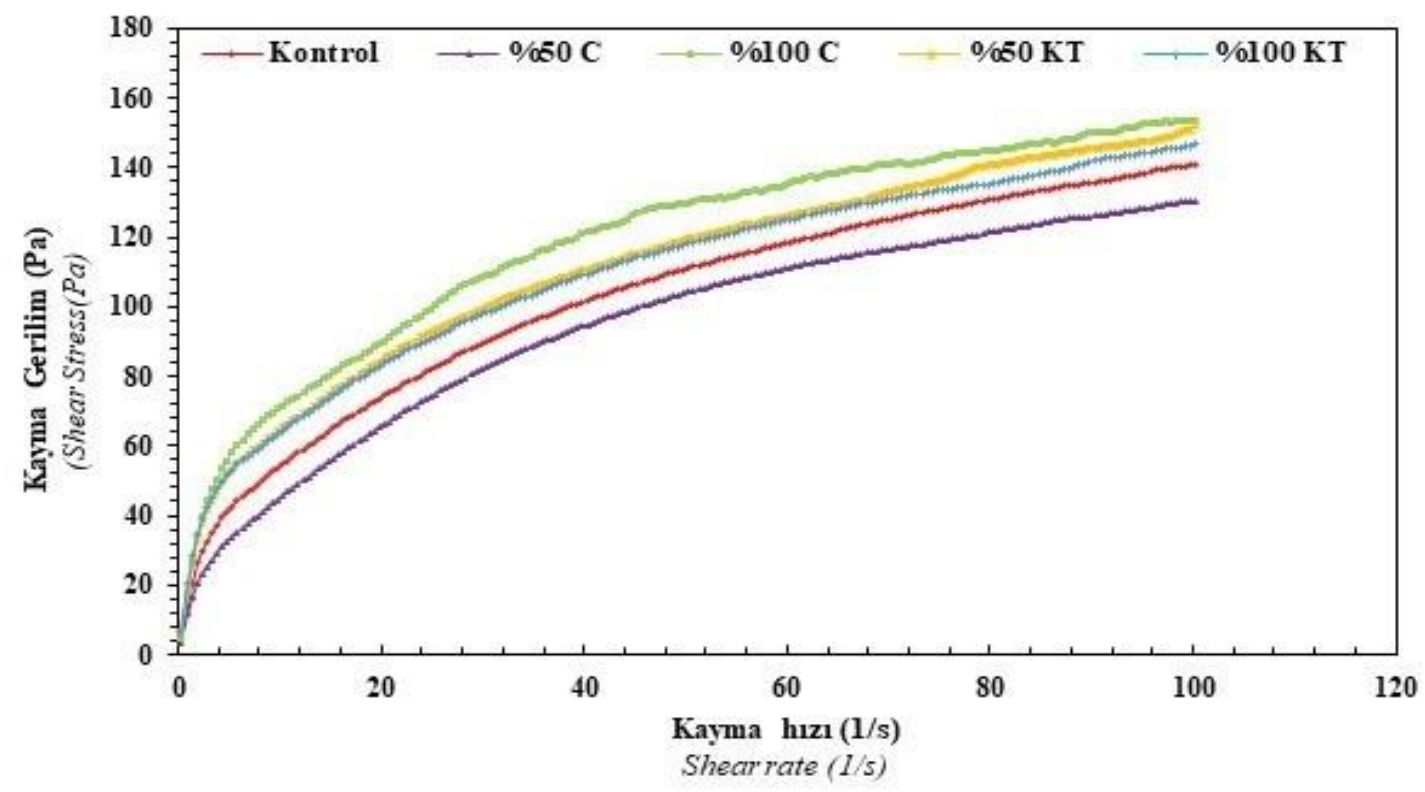

b)

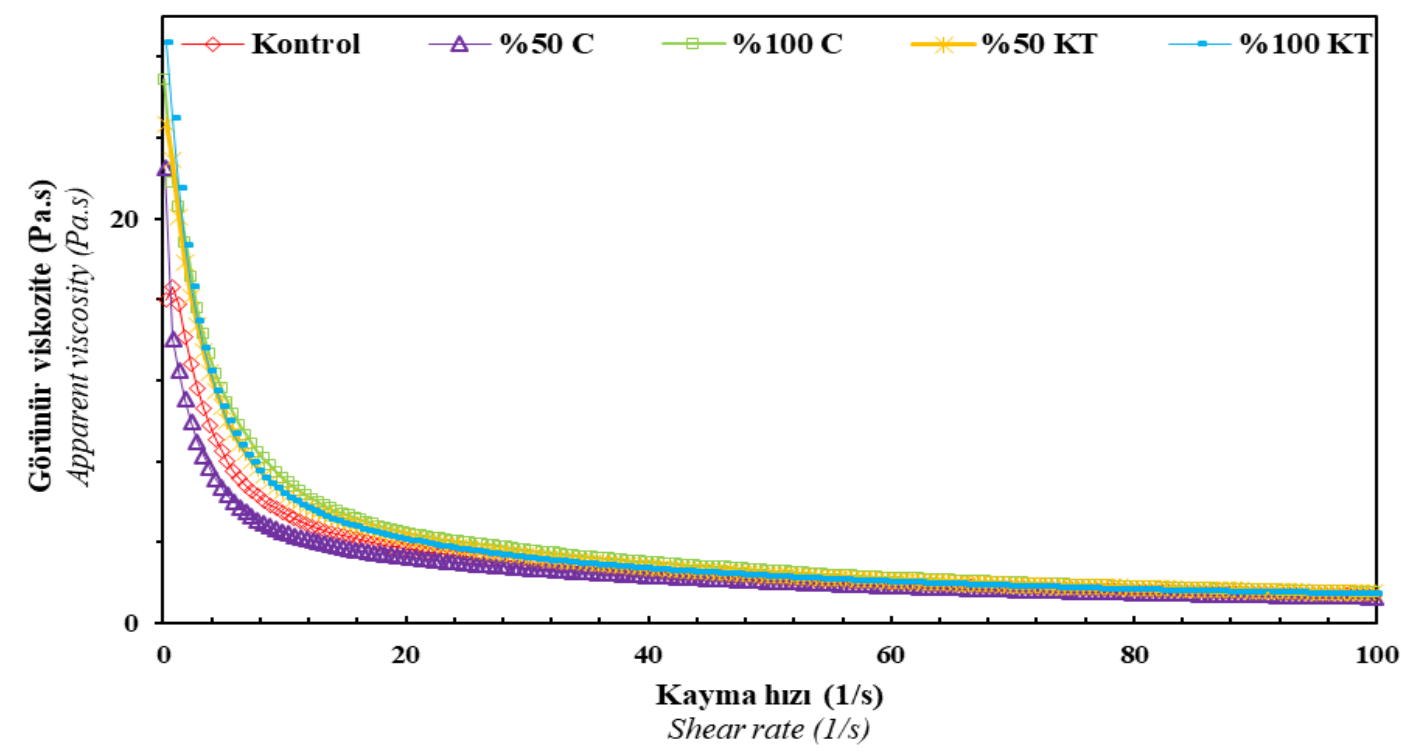

Şekil 2. Farklı oranlarda yumurta ikamesi içeren örneklere ait akış davranış eğrileri. a) Kayma gerilimi (Pa), b) Görünür viskozite (Pa.s)

Figure 2. Flow ramp analysis curves of pancake samples prepared in different formulations. a) Shear stress (Pa); b) Apparent viscosity (Pa.s) 

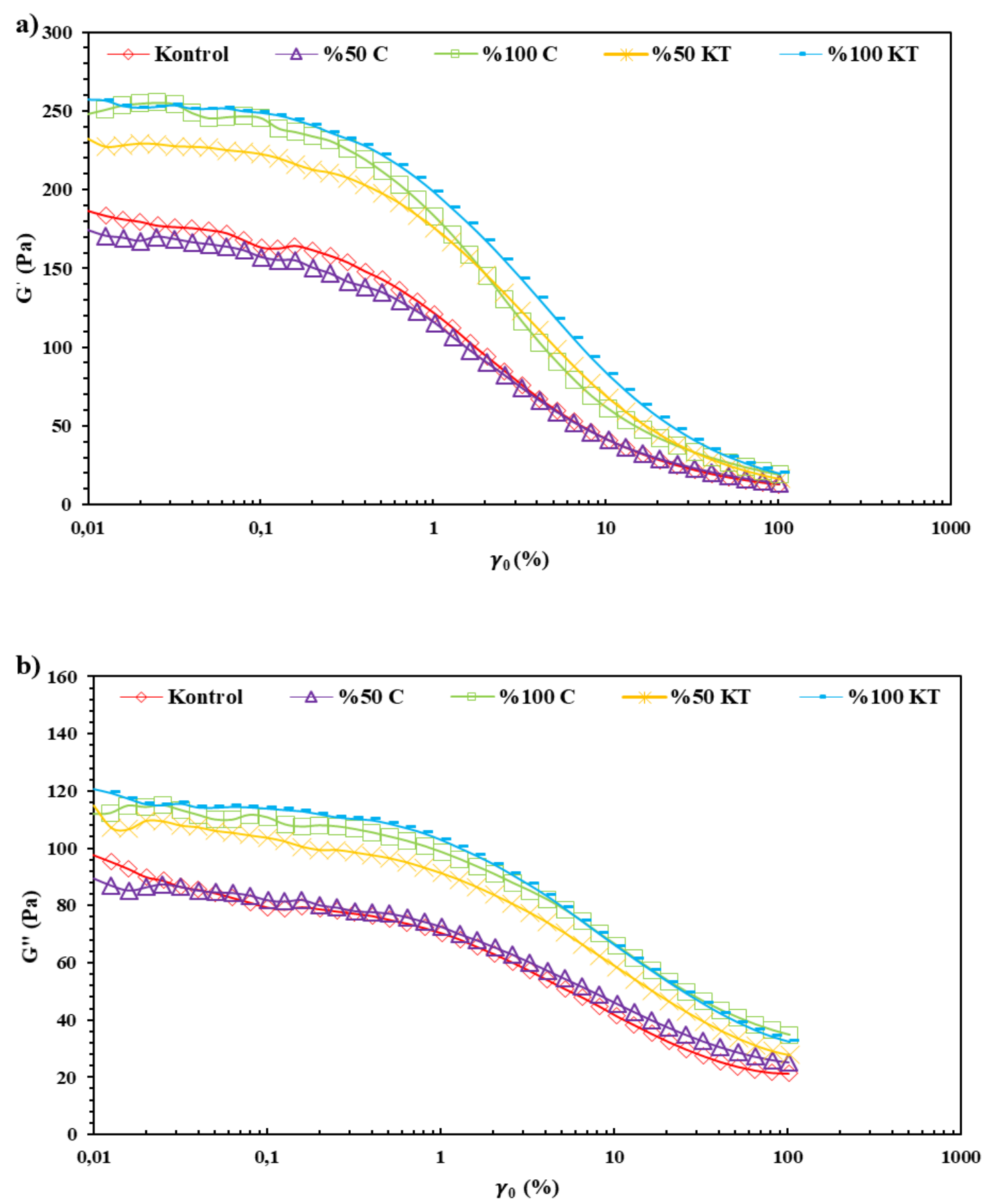

Şekil 3. Farklı oranlarda yumurta ikamesi içeren örneklere ait salınım genliği analizi sonucunda elde edilen viskoelastik modül değerleri. a) $G^{\prime}$, b) $G^{\prime \prime}(10 \mathrm{rad} / \mathrm{s})$

Figure 3. Oscillation amplitude analysis results of pancake batters for different seed gels concentraions at $10 \mathrm{rad} / \mathrm{s}$. a)

$$
G^{\prime}, \text { b) } G^{\prime \prime}
$$


Çizelge 5. Hamurların reolojik karakterizasyonu, üssel model ile elde edilen akış özellikleri Table 5. Rheological characterization of batters, results of power law model

\begin{tabular}{|c|c|c|c|}
\hline $\begin{array}{l}\text { Örnek } \\
\text { (Sample) }\end{array}$ & $\begin{array}{l}\text { Kivam indeksi } \\
\text { (Consistency index) } \\
\left(\mathrm{Pa} . \mathrm{s}^{\mathrm{n}}\right)\end{array}$ & $\begin{array}{l}\text { Akış davranış indeki } \\
\text { (Flow bebavior index) } \\
(-)\end{array}$ & $\mathrm{R}^{2}$ \\
\hline $\begin{array}{l}\text { Kontrol } \\
\text { (Control) }\end{array}$ & $22.4 \pm 0.22^{\mathrm{ab}}$ & $0.41 \pm 0.002^{\mathrm{ab}}$ & 0.996 \\
\hline $\begin{array}{l}\% 50 \mathrm{KT} \\
(50 \% \mathrm{FS})\end{array}$ & $28.77 \pm 0.22^{\mathrm{bc}}$ & $0.36 \pm 0.002^{\mathrm{bc}}$ & 0.998 \\
\hline $\begin{array}{l}\% 100 \mathrm{KT} \\
(100 \% \mathrm{FS})\end{array}$ & $29.25 \pm 0.23 \mathrm{bc}$ & $0.35 \pm 0.002^{c}$ & 0.997 \\
\hline $\begin{array}{l}\% 50 \mathrm{C} \\
(50 \% \mathrm{C})\end{array}$ & $18.33 \pm 0.31^{\mathrm{a}}$ & $0.44 \pm 0.004^{a}$ & 0.990 \\
\hline $\begin{array}{l}\% 100 \mathrm{C} \\
(100 \% \mathrm{C})\end{array}$ & $33.1 \pm 1.29^{c}$ & $0.49 \pm 0.002^{c}$ & 0.987 \\
\hline
\end{tabular}

Cizelge 6. Keten tohumu ve çiya tohumu jelinin yumurta ikamesi olarak kullanımının örneklerin bileșimi üzerine etkisi

Table 6. The effect of using flaxseed and chia seed gel as egg replacers on the composition of the samples

\begin{tabular}{|c|c|c|c|c|}
\hline Örnek (Sample) & $\begin{array}{l}\text { Nem (\%) } \\
\text { (Moisture \%) }\end{array}$ & $\begin{array}{l}\text { Kül (\%) } \\
(A s h \%)\end{array}$ & $\begin{array}{c}\text { Protein (\%)* } \\
\text { (Protein \%) }\end{array}$ & $\begin{array}{l}\text { Ham Yağ }(\%)^{*} \\
\text { (Crude Fat \%) }\end{array}$ \\
\hline $\begin{array}{l}\text { Kontrol } \\
\text { (Control) }\end{array}$ & $45.95 \pm 0.44^{a}$ & $1.88 \pm 0.08^{a}$ & $7.48 \pm 0.46^{c}$ & $9.84 \pm 0.22^{\mathrm{b}}$ \\
\hline $\begin{array}{l}\% 50 \mathrm{KT} \\
(50 \% \mathrm{FS})\end{array}$ & $47.63 \pm 0.03^{b}$ & $1.94 \pm 0.06^{\mathrm{a}}$ & $6.1 \pm 0.07 \mathrm{~b}$ & $9.11 \pm 2.02^{\mathrm{ab}}$ \\
\hline $\begin{array}{l}\% 100 \mathrm{KT} \\
(100 \% \mathrm{FS})\end{array}$ & $48.15 \pm 0.13^{c}$ & $1.96 \pm 0.05^{\mathrm{a}}$ & $5.41 \pm 0.82^{\mathrm{ab}}$ & $9.37 \pm 1.01^{\mathrm{b}}$ \\
\hline $\begin{array}{l}\% 50 \mathrm{C} \\
(50 \% \mathrm{C})\end{array}$ & $49.54 \pm 0.09^{\mathrm{d}}$ & $1.99 \pm 0.03^{\mathrm{a}}$ & $5.47 \pm 0.18^{\mathrm{ab}}$ & $8.31 \pm 1.62^{\mathrm{ab}}$ \\
\hline $\begin{array}{l}\% 100 \mathrm{C} \\
(100 \% \mathrm{C})\end{array}$ & $49.85 \pm 0.24^{\mathrm{d}}$ & $1.98 \pm 0.02^{\mathrm{a}}$ & $4.4 \pm 0.26^{\mathrm{a}}$ & $6.85 \pm 0.31^{\mathrm{a}}$ \\
\hline
\end{tabular}

Aynı sütunda bulunan değerler arasında farklı harf içeren örnekler arasında istatistiksel olarak anlamlı fark bulunmaktadır $(P$ $<0.05)$.

Different letters in the same column $(a, b, c, d)$ indicate significant differences between means $(P<0.05)$.

*Kuru temelde * Dry basis

Çizelge 7. Pankek örneklerinin doku profili sonuçları Table 7. Texture profile results of pancake samples

\begin{tabular}{|c|c|c|c|c|c|c|}
\hline $\begin{array}{l}\text { Örnek } \\
\text { (Sample) }\end{array}$ & $\begin{array}{l}\text { Sertlik (g) } \\
\text { (Hardness) }\end{array}$ & $\begin{array}{l}\text { Esneklik } \\
\text { (Springiness) }\end{array}$ & $\begin{array}{l}\text { Yapışkanlık } \\
\text { (Cohesiveness) }\end{array}$ & $\begin{array}{l}\text { Sakızımsilik } \\
\text { (Gumminess) }\end{array}$ & $\begin{array}{l}\text { Çiğnenebilirlik (g) } \\
\text { (Chewiness) }\end{array}$ & $\begin{array}{l}\text { Elastiklik } \\
\text { (Resilience) }\end{array}$ \\
\hline $\begin{array}{l}\text { Kontrol } \\
\text { (Control) }\end{array}$ & $2766.94 \pm 94 c$ & $0.99 \pm 0.05^{\mathrm{a}}$ & $0.73 \pm 0.05^{c}$ & $1786.55 \pm 283.66^{\mathrm{ab}}$ & $1768.68 \pm 277.46^{\mathrm{ab}}$ & $0.39 \pm 0.06^{\mathrm{a}}$ \\
\hline $\begin{array}{l}\% 50 \mathrm{KT} \\
(50 \% \mathrm{FS})\end{array}$ & $1917.3 \pm 220,64 \mathrm{ab}$ & $1.04 \pm 0.11^{\mathrm{a}}$ & $0.71 \pm 0.05^{\mathrm{ab}}$ & $1372.76 \pm 224.58^{\mathrm{ab}}$ & $1441.45 \pm 373.03^{\mathrm{ab}}$ & $0.36 \pm 0.04^{a}$ \\
\hline $\begin{array}{l}\% 100 \mathrm{KT} \\
(100 \% \text { FS })\end{array}$ & $3028.69 \pm 223.46^{c}$ & $1.02 \pm 0.04^{\mathrm{a}}$ & $0.73 \pm 0.01^{\mathrm{c}}$ & $1929.83 \pm 384.90^{\mathrm{b}}$ & $1972.64 \pm 408.81^{b}$ & $0.35 \pm 0.03^{\mathrm{a}}$ \\
\hline $\begin{array}{l}\% 50 \mathrm{C} \\
(50 \% \mathrm{C})\end{array}$ & $2128.01 \pm 94.52^{\mathrm{b}}$ & $0.95 \pm 0.02^{\mathrm{a}}$ & $0.7 \pm 0.04^{\mathrm{ab}}$ & $1451.43 \pm 518.85^{\mathrm{ab}}$ & $1386.91 \pm 516.81^{\mathrm{ab}}$ & $0.34 \pm 0.02^{\mathrm{a}}$ \\
\hline $\begin{array}{l}\% 100 \mathrm{C} \\
(100 \% \mathrm{C})\end{array}$ & $1495.08 \pm 208.93^{a}$ & $0.92 \pm 0.04^{\mathrm{a}}$ & $0.63 \pm 0.05^{\mathrm{a}}$ & $1188.05 \pm 258.37 \mathrm{a}$ & $1095.396 \pm 202.97 \mathrm{a}$ & $0.30 \pm 0.05^{\mathrm{a}}$ \\
\hline
\end{tabular}

Aynı sütunda bulunan değerler arasında farklı harf içeren örnekler arasında istatistiksel olarak anlamlı fark bulunmaktadır $(P$ $<0.05$ ).

Different letters in the same column $(a, b, c)$ indicate significant differences between means $(P<0.05)$. 
Renk

Pankek örneklerinin iç ve diş renk karakteristiklerini ifade eden $L^{*}, a^{*}$ ve $b^{*}$ değerleri Çizelge 8'de verilmiştir. Örneklerin parlaklı̆̆ını ifade eden $L^{*}$ değerleri, iç ve dış kısım için en yüksek \%50 çiya tohumu jeli içeren örneğe ait olduğu tespit edilmiştir $(P<0.05)$. Örneklerin kırmızıllı̆ını ifade eden $a^{*}$ değerleri incelendiğinde iç kısımda en çok \%100 çiya tohumu jeli içeren örneğe ait olduğu belirlenmiş olup; bu durumun formülasyon içerisinde birakılan çiya tohumlarından kaynaklandığ1 düşünülmektedir. Benzer şekilde Fernandes ve Salas-Mellado
(2017), kek örneklerinde yağ ikamesi olarak çiya jeli kullanımı sonucunda örneklerde çiya jeli oranı arttıkça kabuk L* ve a* değerlerinde artı̧ eğilimi, b* değerinde ise anlamlı bir fark olmadığı belirtilmiştir. Kek örneklerinin iç rengi ise çiya jeli oranı arttıkça $L^{*}$ değerinde artış, $a^{*}$ ve $b^{*}$ değerlerinde azalma olduğu tespit edilmiştir. Kabuk renk değerlerinde ise çalışmalarda, keten tohumu içeren keklerin kontrol örneği ile kıyaslandığında $\mathrm{L}^{*}$ değerinde azalma gözlemlendiği, $a^{*}$ ve $b^{*}$ değerlerinde ise artış gözlemlendiği belirtilmektedir (Korus vd., 2015; Levent vd., 2020).

Çizelge 8. Farklı formülasyonlarda hazırlanan pankek örneklerinin iç ve dış renk değerleri

Table 8. Pancake crumb and crust color values of pancake samples prepared in different formulations

\begin{tabular}{|c|c|c|c|c|c|c|}
\hline \multirow{2}{*}{ Örnek (Sample) } & \multicolumn{3}{|c|}{$\begin{array}{c}\text { İÇ } \\
\text { (Crumb) }\end{array}$} & \multicolumn{3}{|c|}{$\begin{array}{c}\text { DISS } \\
\text { (Crust) }\end{array}$} \\
\hline & $\mathrm{L}^{*}$ & $a^{*}$ & $b^{*}$ & $\mathrm{~L}^{*}$ & $a^{*}$ & $\mathrm{~b}^{*}$ \\
\hline Kontrol (Control) & $68.69 \pm 1.52^{b c}$ & $-0.85 \pm 0.19 \mathrm{ab}$ & $16.19 \pm 0.94 \mathrm{ab}$ & $44.06 \pm 3.01^{\mathrm{a}}$ & $10.85 \pm 1.14^{c}$ & c $28.34 \pm 3.17 \mathrm{a}$ \\
\hline$\% 50 \mathrm{KT}(50 \%$ FS) & $66.78 \pm 0.93^{b}$ & $-0.91 \pm 0.71^{\mathrm{ab}}$ & $17.01 \pm 1.83^{c}$ & $51.42 \pm 1.96^{\mathrm{b}}$ & $8.20 \pm 0.36^{\mathrm{bc}}$ & $=29.01 \pm 2.59^{a}$ \\
\hline$\% 100 \mathrm{KT}(100 \%$ FS) & $68.16 \pm 2.45^{b c}$ & $-1.71 \pm 0.29^{a}$ & $15.33 \pm 1.41^{b c}$ & $61.87 \pm 3.33^{c}$ & $4.45 \pm 2.61^{\mathrm{a}}$ & $27.26 \pm 5.24 a$ \\
\hline$\% 50$ C $(50 \% C)$ & $72.74 \pm 1.96^{c}$ & $-1.46 \pm 0.04^{a}$ & $14.23 \pm 0.43^{\mathrm{ab}}$ & $62.32 \pm 0.82^{c}$ & $6.05 \pm 1.00^{\mathrm{ab}}$ & $29.64 \pm 2.25^{a}$ \\
\hline$\% 100$ C $(100 \%$ C) & $58.18 \pm 4.08^{\mathrm{a}}$ & $-0.26 \pm 0.59^{b}$ & $13.05 \pm 0.23^{\mathrm{a}}$ & $48.61 \pm 3.46^{\mathrm{ab}}$ & $9.72 \pm 1.86^{c}$ & $30.19 \pm 0.82^{a}$ \\
\hline
\end{tabular}

Aynı sütunda bulunan değerler arasında farklı harf içeren örnekler arasında istatistiksel olarak anlamlı fark bulunmaktadır $(P<0.05)$.

Different letters in the same column $(a, b, c)$ indicate significant differences between means $(P<0.05)$.

\section{Duyusal Özellikler}

Pankek örneklerinin duyusal karakteristikleri olan, renk, doku, görünüş, lezzet ve genel beğeni sonuçları Çizelge 9'da verilmektedir. Sonuçlar, çiya tohumu jeli ve keten tohumu jeli kullanımının örneklerin renk ve doku özellikleri üzerine anlamlı bir etkisi olmadığını ortaya koymuştur $(P>0.05)$. $\% 100$ C örneği lezzet açısından panelistler tarafindan en az puan alan örnek olmuştur $(P$ $<0.05)$. Pankek formülasyonuna çiya ve keten tohumu jellerinin artan oranlarda ilavesi ile genel beğeninin azaldığı saptanmıştır $(P<0.05)$. Genel beğeni skalasında en beğenilen örnek kontrol örneği olmakla birlikte, $\% 50$ keten tohumu jeli içeren örnekle arasında anlamlı bir fark bulunmamıştır $(P>0.05)$. Benzer şekilde kek örneklerinde yumurta ikamesi olarak çiya tohumu (Borneo vd., 2010) ve keten tohumunun
(Nugraheni vd., 2019) kullanılmasiyla genel beğeni değerlerinin azaldığı tespit edilmiştir.

\section{SEM}

Yumurta içeren ve içermeyen pankek örneklerinin makro ve mikro yapısının belirlenmesi amacıyla taramalı elektron mikroskobu kullanılmıştır. Farklı oranlarda kullanılan çiya tohumu jeli ve keten tohumu jeli ile üretilen pankek örneklerinin x1000 büyütme oranı ile mikrografları Şekil 5'te verilmiştir. Pankek örneklerinin mikrografları incelendiğinde, çiya tohumu jeli ve keten tohumu jeli oranının artmasıyla, gözenekliliğin azaldığı görülmektedir. Formülasyondaki çiya tohumu jelinin artması ile örneğin daha katmanlı ve kırılgan bir yapı gösterdiği gözlemlenmiştir. \%100 çiya tohumu jeli içeren örneğin diğer örneklere göre daha kırılgan olduğu görülmektedir. $\% 100$ keten tohumu jeli ile hazırlanan örnek ile \%100 
çiya tohumu ile hazırlanan örnek karşılaştırıldığında, \%100 keten tohumu jeli içeren örneğin kontrol örneğine daha benzer olduğu gözlemlenmiştir. Paraskevopoulou vd. (2015) tarafindan yapılan çalışmada kek örneklerinde peynir altı suyu izolatı kullanılarak yumurta oranının azaltılması ile örneklerde gözenekliliğin azaldığı belirtilmiştir.
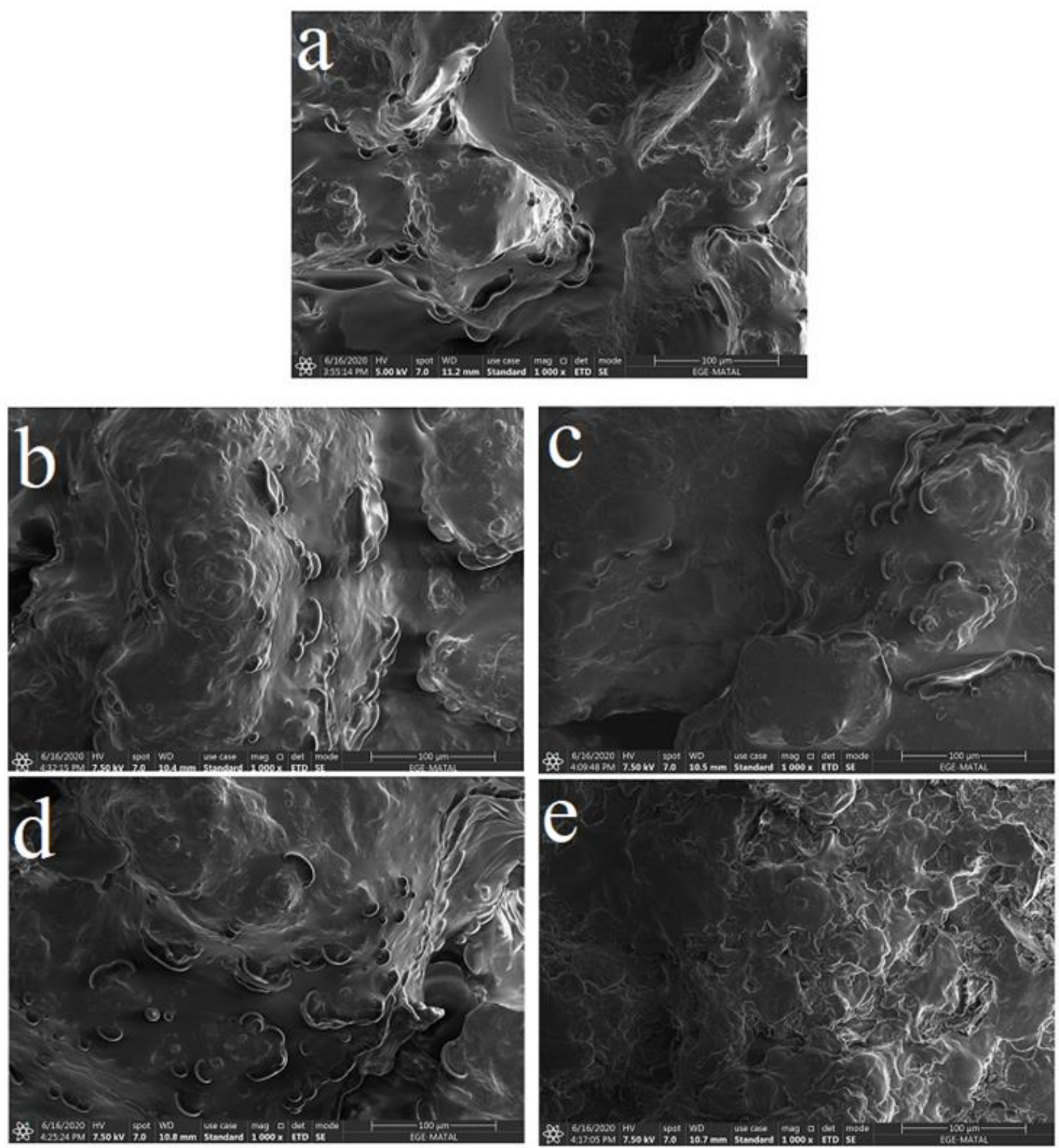

Şekil 5. Taramalı elektron mikroskobu görüntüleri a) K, b) \%50 KT, c) \%50 C, d) \%100 KT, e) \%100 $\mathrm{C}$

Figure 5. Scanning electron microscope images a) K, b) \%50 FS, c) \%50 C, d) \%100 FS, e) $\% 100 \mathrm{C}$ 
Çizelge 9. Farklı oranlarda çiya tohumu jeli ve keten tohumu jeli içeren pankeklere ait duyusal analiz sonuçları

Table 9. Sensory properties of pancakes containing different proportions of chia seed gel and flaxseed gel

\begin{tabular}{lccccc}
\hline $\begin{array}{l}\text { Örnek } \\
\text { (Sample) }\end{array}$ & $\begin{array}{c}\text { Görünüş } \\
\text { (Apperance) }\end{array}$ & $\begin{array}{c}\text { Renk } \\
\text { (Color) }\end{array}$ & $\begin{array}{c}\text { Doku } \\
\text { (Texture) }\end{array}$ & $\begin{array}{c}\text { Lezzet } \\
\text { (Taste) }\end{array}$ & $\begin{array}{c}\text { Genel Beğeni } \\
\text { (Overall acceptance) }\end{array}$ \\
\hline Kontrol (Control) & $4.56 \pm 0.43^{\mathrm{c}}$ & $4.22 \pm 0.28^{\mathrm{a}}$ & $4.18 \pm 0.28^{\mathrm{a}}$ & $4.6 \pm 0.21^{\mathrm{b}}$ & $4.63 \pm 0.21^{\mathrm{b}}$ \\
$\% 50 \mathrm{KT}(50 \% \mathrm{FS})$ & $4.09 \pm 0.19^{\mathrm{a}}$ & $4.28 \pm 0.29^{\mathrm{a}}$ & $4.25 \pm 0.26^{\mathrm{a}}$ & $4.54 \pm 0.16^{\mathrm{b}}$ & $4.60 \pm 0.20^{\mathrm{b}}$ \\
$\% 100 \mathrm{KT}(100 \% \mathrm{FS})$ & $4.25 \pm 0.26^{\mathrm{ab}}$ & $4.31 \pm 0.26^{\mathrm{a}}$ & $4.18 \pm 0.28^{\mathrm{a}}$ & $4.43 \pm 0.33^{\mathrm{b}}$ & $4.02 \pm 0.30^{\mathrm{a}}$ \\
$\% 50 \mathrm{C}(50 \%$ C) & $4.4 \pm 0.21^{\mathrm{bc}}$ & $4.26 \pm 0.27^{\mathrm{a}}$ & $4.30 \pm 0.25^{\mathrm{a}}$ & $4.39 \pm 0.20^{\mathrm{b}}$ & $3.98 \pm 0.06^{\mathrm{a}}$ \\
$\% 100 \mathrm{C}(100 \%$ C) & $4.12 \pm 0.25^{\mathrm{a}}$ & $4.23 \pm 0.26^{\mathrm{a}}$ & $4.27 \pm 0.28^{\mathrm{a}}$ & $3.97 \pm 0.09^{\mathrm{a}}$ & $3.86 \pm 0.22^{\mathrm{a}}$
\end{tabular}

Aynı sütunda bulunan değerler arasında farklı harf içeren örnekler arasında istatistiksel olarak anlamlı fark bulunmaktadır $(P<0.05)$.

Different letters in the same column $(a, b, c)$ indicate significant differences between means $(P<0.05)$.

\section{SONUÇ}

Hayvansal protein kullanımına alternatif olarak bitkisel proteinlerden çiya tohumu jeli ve keten tohumu jelinin pankek örneklerinde yumurta beyazına alternatif olarak kullanılabilirliği araştırılmıştır. Sonuçlar, üssel model kullanılarak örneklerin akış davranış özelliklerinin başarılı bir şekilde tanımlandığını ve örneklerin kayma ile incelen yap1 gösterdiğini ortaya koymuştur. Tohum jellerinin yüksek su absorplama indeksine sahip olmasından dolayı pankek hamurlarının viskozite değerlerinde genel bir artış gözlemlenmiştir. Aynı zamanda tohum jellerinin yüksek su absorplama kapasitesine bağlı olarak pankek örneklerinin nem içeriklerinde kontrol grubu ile kıyaslandığında artış görülmektedir ( $P$ $<0.05)$. Duyusal değerlendirme sonucunda örneklerin genel kabul edilebilirliğinin yüksek olduğu belirlenmiş ve panelistler tarafindan örnekler arasında renk ve doku açısından fark bulunamamıştır $(P$ >0.05). Yumurta ikamesi olarak çiya ve keten tohumu jeli kullanımı hamur örneklerinin reolojik özelliklerini geliştirmekte ve yumurta alerjisi, vegan diyet tercihleri gibi nedenlerle yumurta tüketmeyen bireylerin tüketimine uygun, tamamen bitkisel kaynaklı yumurta ikamesi içeren pankek üretimi gerçekleştirilmiştir. Sonuç olarak çalışma, yumurta beyazı ikamesi olarak çiya tohumu jeli ve keten tohumu jeli kullanıminın yumurta ile benzer fonksiyonel özellikler gösterebileceğini ve pankek örneklerinde kullanımı için uygun ve ucuz bir alternatif olduğunu ortaya koymuştur. Son y1llarda fonksiyonel özellikleriyle ilgi çekmeye başlayan bitkisel proteinlerden çiya ve keten tohumu ile yapılan çalışmalara yenilikçi bir çalışmayla katkı sağlanmıştır.

\section{ÇIKAR ÇATIŞMASI}

Yazarların makale ile ilgili başka kişiler veya kurumlar ile çıkar çatışması bulunmamaktadır.

\section{YAZAR KATKILARI}

Şebnem TAVMAN ve Seher KUMCUOĞLU çalışma konusu belirleme, yöntem, makalenin yazımı ve danışmanlık kısımlarında katkı sağlamışlardır. Selen ERKOÇ, İpek ÖZCAN ve Esra ÖZYİĞİT analizlerin gerçekleştirilmesi, sonuçların istatistiksel değerlendirilmesi, yorumlanması ve makalenin yazım aşamalarında görev almışlardır. Tüm yazarlar tarafindan makalenin son hali okunmuş ve onaylanmıştır.

\section{KAYNAKLAR}

Agrahar-Murugkar, D., Zaidi, A., Kotwaliwale, N., Gupta, C. (2016). Effect of egg-replacer and composite flour on physical properties, color, texture and rheology. nutritional and sensory profile of cakes. J Food Qual, 39(5): 425-435, doi: 10.1111/jfq.12224.

Altuğ Onoğur, T., Elmac1, Y. (2015). Gidalarda Duyusal Değerlendirme. Sidas Medya, İzmir, Türkiye, 135s. ISBN:978-9944-5660-8-7.

Borneo, R., Aguirre, A., León, A. E. (2010). Chia (Salvia hispanica L.) gel can be used as egg or oil replacer in cake formulations. J the Am Diet Assoc, 110(6): 946-949, doi: 10.1016/j.jada.2010.03.011. 
Boye, J. I., Aksay, S., Roufik, S., Ribéreau, S., Mondor, M., Farnworth, E., Rajamohamed, S. H. (2010). Comparison of the functional properties of pea, chickpea and lentil protein concentrates processed using ultrafiltration and isoelectric precipitation techniques. Food Res Int, 43(2): 53754, doi: 10.1016/j.foodres.2009.07.021.

Bozdogan, N., Kumcuoglu, S., Tavman, S. (2019). Investigation of the effects of using quinoa flour on gluten-free cake batters and cake properties. $J$ Food Sci Technol 56, 683-694, doi: 10.1007/s13197-018-3523-1.

Chen, H. H., Xu, S. Y., Wang, Z. (2006). Gelation properties of flaxseed gum. J Food Eng, 77(2): 295303, doi: 10.1016/j.jfoodeng.2005.06.033.

Cho, E., Kim, J. E., Baik, B. K., Chun, J. B., Ko, H., Park, C., Cho, S. W. (2019). Influence of physicochemical characteristics of flour on pancake quality attributes. J Food Sci Technol, 56(3): 1349-1359, doi: 10.1007/s13197-019-03607-x.

Choi, I, Han, O. K., Chun J., Kang, C. S., Kim, K. H., Kim, Y. K., Cheong, Y. K., Park, T. I., Choi, J. S., Kim, K. J. (2012). Hydration and pasting properties of oat (avena sativa) flour. Prev Nutr Food Sci, 17(1): 87-91, doi: 10.3746/ pnf.2012.17.1.087.

Coorey, R., Tjoe, A., Jayasena, V. (2014). Gelling properties of chia seed and flour. J. Food Sci, 79(5): e859-e866, doi: 10.1111/1750-3841.12444.

Çetiner, M., Ersus-Bilek, S. (2018). Bitkisel protein kaynakları. Cukurova Tarm ve Gida Bilimleri Dergisi, 33(2): 111-126.

Darwish, A., Khalifa, R. E., El-Sohaimy, S. A. (2018). Functional properties of chia seed mucilage supplemented in low fat yoghurt. Alex Sci Exch J, 39(3): 450-459, doi: 10.21608/asejaiqjsae.2018.13882.

Deng, Y., Chen, J., Huang, J., Yang, X., Zhang, X., Yuan, S., Liao, W. (2020). Preparation and characterization of cellulose/flaxseed gum composite hydrogel and its hemostatic and wound healing functions evaluation. Cellulose, 27: 3971-3988, doi: 10.1007/s10570-020-03055-3.

El-Sayed, M. A., Shaltout, O. E., El-Difrawy, E. A. (2014). Production and evaluation of low fat cake containing flaxseed and okra gums as a fat replacer. Alex J Food Sci Technol, 11(1): 53-60, doi: 10.12816/0025350.

Fajardo, C.A., Ross, A.S. (2015). Exploring relationships between pancake quality and grain and flour functionality in soft wheats. Cereal Chem, 92: 378-383, doi: 10.1094/CCHEM-08-14-0173R.

Fang, S., Qiu, W., Mei, J., Xie, J. (2020). Effect of sonication on the properties of flaxseed gum films incorporated with carvacrol. Int J Mol Sci Artic, (21): 1637, doi: 10.3390/ijms21051637.

Fernandes, S., S., Salas-Mellado, M. (2017). Addition of chia seed mucilage for reduction of fat content in bread and cakes. Food Chem, 227 (2017): 237-244, doi: 10.1016/j.foodchem. 2017.01.075.

Finnie, S. M., Bettge, A. D., Morris, C. F. (2006). Influence of flour chlorination and ingredient formulation on the quality attributes of pancakes. Cereal Chem, 83(6): 684-691, doi: 10.1094/CC-830684.

Gallo, L. R. D. R., Assunção Botelho, R. B., Ginani, V. C., de Lacerda de Oliveira, L., Riquette, R. F. R. ve Leandro, E. D. S. (2020). Chia (Salvia bispanica L.) gel as egg replacer in chocolate cakes: applicability and microbial and sensory qualities after storage. J Culinary Sci Technol, 18(1): 29-39, doi: 10.1080/15428052.2018.1502111.

Gómez, M., Ronda, F., Caba1llero, P. A., Blanco, C. A., Rosell, C. M. (2007). Functionality of different hydrocolloids on the quality and shelflife of yellow layer cakes. Food Hydrocoll, 21: 167173, doi: 10.1016/j.foodhyd.2006.03.012.

Gularte, A. G., de la Hera, E., Gómez, M., Rosell, C. M. (2012). Effect of different fibers on batter and gluten-free layer cake properties. LWT-J Food Sci Technol, 48(2012): 209-214, doi: 10.1016/j.lwt.2012.03.015

Hargreaves, S. M., Zandonadi, R. P. (2018). Flaxseed and chia seed gel on characteristics of gluten-free cake. J Culinary Sci Technol, 16(4): 378388, doi: 10.1080/15428052.2017.1394951.

Hatamian, M., Noshad, M., AbdananMehdizadeh, S., Barzegar, H. (2020). Effect of roasting treatment on functional and antioxidant 
properties of chia seed flours. NFS J, 21: 1-8. doi: 10.1016/j.nfs.2020.07.004

Hrncic, M. K., Ivanovski, M., Cör, D., Knez, Z. (2020). Chia seeds (Salvia Hispanica L.): An oveview-phytochemical profile, isolation methods and application. Mol, 25(1): 11, doi: 10.3390/molecules25010011.

Incoronato, A. L., Cedola A., Conte, A., Del Nobile, M. A. (2020). Juice and by-products from pomegranate to enrich pancake: characterization and shelf-life evaluation. Inst Food Scie Technol, 56(6): 2886-2894, doi: 10.1111/ijfs.14926.

İşleroğlu, H. ve Yıldırım, Z. Y. M. (2005). Fonksiyonel Bir Gida Olarak Keten Tohumu. Gaziosmanpaşa Üniversitesi Ziraat Fakültesi Dergisi, 22(2): 23-30.

Kajla, P. Sharma, A., Sood D.R. (2015). Flaxseeda potential functional food source. I Food Sci Technol, 52(4): 1857-1871, doi: 10.1007/s13197014-1293-y.

Kohrs, D. Heralds, T.J., Armanouni, F.M. Abu Ghoush, M. (2010). Evaluation of egg-replacers in a yellow cake system. J Food Agric, 22, 340-352.

Koocheki, A., Mortazavia, S.A., Shahidia, F., Razavia, S.M.A., Taherian, A.R. (2009). Rheological properties of mucilage extracted from Alyssum homolocarpum seed as a new source of thickening agent. J Food Eng, 91(3): 490-496, doi: 10.1016/j.jfoodeng.2008.09.028.

Korus, J., Witczak, T., Ziobro R., Juszczak L. (2015). Linseed (Linum usitatissimum L.) mucilage as a novel structure forming agent in gluten-free bread. LWT-J Food Sci Technol, 62(2015): 257-264, doi: 10.1016/j.lwt.2015.01.040.

Kumar, R. K., Bejkar, M., Du, S., Serventi, L. (2019). Flax and wattle seed powders enhance volume and softness of gluten-free bread. Food $S_{c i}$ Technol Int, 25(1): 66-75, doi: 10.1177/1082013218795808.

Lee, S., Inglett, G. E., Carriere, C. J. (2004). Effect of nutrim oat bran and flaxseed on rheological properties of cakes. Cereal Chem, 81(5): 637-642, doi: 10.1094/CCHEM.2004.81.5.637.

Levent, H., Sayaslan, A., Yeşil, S. (2020). Physicochemical and sensory quality of gluten- free cakes supplemented with grape seed, pomegranate seed, poppy seed, flaxseed and turmeric. J Food Process Preserv, 45(2): e15148, doi:10.1111/jfpp.15148.

Mannucci, A., Castagna, A., Santin, M., Serra, A., Mele, M., Ranieri, A. (2019). Quality of flaxseed oil cake under different storage conditions. LWTJ Food Sci Technol, 104(2019): 84-90, doi: 10.1016/j.lwt.2019.01.035.

McClements, D. J., Bai, L., Chung, C. (2017). Recent advances in the utilization of natural emulsifiers to form and stabilize emulsions. Ann Rev Food Sci Technol, 8: 205-236, doi: 10.1146/annurev-food-030216-030154.

Mine, Y. (1995). Recent advances in the understanding of egg white protein functionality. Trends Food Sci Technol, 6(7): 225-231, doi: 10.1016/S0924-2244(00)89083-4

Moreira, R., Chenlo, F., Torres, M. D. (2013). Effect of chia (Sativa hispanica L.) and hydrocolloids on the rheology of gluten-free doughs based on chestnut flour. LWT-J Food Sci Technol, 50(1): 160-166, doi: 10.1016/j.lwt.2012.06.008.

Muñoz-González, I., Merino-Álvarez, E., Salvador, M., Pintado, T., Ruiz-Capillas, C., Jiménez-Colmenero, F., Herrero, A. M. (2019). Chia (Salvia hispanica L.) a promising alternative for conventional and gelled emulsions: technological and lipid structural characteristics. Gels, 5(2): 19, doi: 10.3390/gels5020019.

Nugraheni, M., Sutopo-Purwanti, S., Handayani, T. H. W. (2019). Nutritional, physical and sensory properties of high protein gluten and egg-free cookies made with resistant starch type 3 Maranta arundinaceae flour and flaxseed. Food Res, 3(6): 658663, doi: 10.26656/fr.201.

Olivos-Lugo, B.L., Valdivia-López, M.Á., Tecante A. (2010). Thermal and physicochemical properties and nutritional value of the protein fraction of Mexican chia seed (Salvia hispanica L.). Food Sci Tecbnol Int, 16(1): 89-96, doi: 10.1177/1082013209353087.

Özbek, T., Yeşilçubuk, N. Ş. (2018) Süper Besin: Chia Tohumu (Salvia Hispanica L.). Beslenme ve 
Diyet Dergisi, 46(1): 90-96, doi: 10.33076/ 2018.BDD.292.

Paraskevopoulou, A., Donsouzi, S., Nikiforidis, C. V., Kiosseoglou, V. (2015) Quality characteristics of egg-reduced pound cakes following WPI and emulsifier incorporation. Food Res Int, 69: 72-79, doi: j.foodres.2014.12.018.

Rabetafika, H. N., Van Remoortel, V., Danthine, S., Paquot, M., Blecker, C. (2011). Flaxseed proteins: food uses and health benefits. Int J Food Sci Technol, 46(2): 221-228, doi: 10.1111/j.13652621.2010.02477.x.

Ronda, F., Oliete, B., Gómez, M., Caballero, P.A., Pando, V. (2011). Rheological study of layer cake batters made with soybean protein isolate and different starch sources. J Food Eng, 102(3): 272277, doi: 10.1016/j.jfoodeng.2010.09.001.

Rosas-Mendoza, M. E., Coria-Hernández, J., Meléndez-Pérez, R., Arjona-Román, J. L. (2017). characteristics of chia (Salvia bispanica L.) seed oil extracted by ultrasound assistance. J Mex Chem Soc, 61(4): 326-335.

Safdar, B., Pang, Z., Liu, X., Jatoi, M. A., Mehmood, A., Rashid, M. T., Ali, N., Naveed, M. (2019). Flaxseed gum: Extraction, bioactive composition, structural characterization, and its potential antioxidant activity. J Food Biochem, 43: e13014, doi: 10.1111/ jfbc.13014.

Safdar, B., Pang, Z., Liu, X., Rashid, M.T., Jatoi, M.A. (2020). Structural and functional properties of raw and defatted flaxseed flour and degradation of cynogenic contents using different processing methods. J Food Process Eng, 43: e13406, doi: 10.1111/jfpe.13406.

Sharif, H. R., Williams, P. A., Sharif, M. K., Abbas, S., Majeed, H., Masamba, K. G., Zhong, F. (2018). Current progress in the utilization of nati and modified legume proteins as emulsifiers and encapsulants - A review. Food Hydrocoll, 76(Nomber 2017): 2-16, doi: 10.1016/j.foodhyd. 2017.01.002.

Shevkani, K., Kaur, A., Kumar, S., Singh, N. (2015). Cowpea protein isolates: Functional properties and application in gluten-free rice muffins. LWT-J Food Sci Technol, 63(2): 927-933, doi: 10.1016/j.lwt.2015.04.058.

Shi, Z., Yuan, B., Zhang, C., Zhou, M., HolmboeOttesen, G. (2011). Egg consumption and the risk of diabetes in adults, Jiangsu, China. Nutr, 27(2): 194-198. doi: 10.1016/j.nut.2010.01.012.

Shih, F. F., Truong, V. D., Daigle, K. W. (2006). Physicochemical properties of Gluten-free pancakes from rice and sweet potato flours. J Food Qual, 29(1): 97-107, doi: 10.1111/j.17454557.2005.00059.x.

Singh, R.P., Heldman, D.R. (2014). Introduction to food engineering, 4th Edition, Academic Press, Amsterdam, Netherlands, 155-160p. ISBN: 9780-12-398530-9.

Steffe J.F. (1996). Rheological methods in food process engineering, 2nd Edition. Freeman Press, East Lansing, USA, 294-348p.

Tan, M.C., Chin, N.L., Yusof, Y.A., Taup, F.S., Abdullah, J. (2015). Improvement of eggless cake structure using ultrasonically treated whey protein. Food Bioprocess Technol. 8: 605, doi: 10.1007/s11947-014-1428-1.

Tirgar, M., Silcock, P., Carne, A., Birch, E.J. (2017). Effect of extraction method on functional properties of flaxseed protein concentrates. Food Chem, 215: 417-424, doi: 10.1016/j.foodchem.2016.08.002.

Uysal, R., Boyac1, İ. H., Sumnu, G. (2019). Determination of pasteurization treatment of liquid whole egg by measuring physical and rheological properties of cake cream. J Food Process Eng., 42: e13167, doi: 10.1111/jfpe.13167.

Weipert, D. (1990). The benefits of basic rheometry in studying dough rheology. Cereal Chem. 67(4): 311-317.

Yurt, M., Gezer, C. (2018). Chia tohumunun (salvia hispanica) fonksiyonel özellikleri ve sağlık üzerine etkileri. Gida, 43(3): 446-460, doi: 10.15237/gida.GD17093.

Zettel, V. Hitzmann, B. (2018). Applications of chia (Salvia hispanica L.) in food products. Trends Food Sci Technol, 80: 43-50, doi: 10.1016/j.tifs.2018.07.011 